\title{
The Impact of Governmental Accounting Standards on Public-Sector Pension Funding
}

\author{
Divya Anantharaman \\ Associate Professor \\ Rutgers Business School \\ Department of Accounting and Information Systems \\ 1 Washington Park Room 916 \\ Newark, NJ 07102 \\ divyaa@rutgers.edu \\ Elizabeth Chuk* \\ Associate Professor \\ University of California, Irvine \\ 4293 Pereira Drive SB2 413 \\ Irvine, CA 92697 \\ elizchuk@uci.edu
}

First Draft: January 31, 2018

This Draft: November 30, 2019

\begin{abstract}
The funding policy for defined benefit pension plans covering government employees represents an important decision for government entities sponsoring those plans. In recent years, a number of state and local governments have experienced extreme funding shortfalls (e.g., New Jersey, Illinois, and Detroit), raising concerns about whether government entities are contributing enough to their pensions. Governmental Accounting Standards Board Statements Number 67/68 (hereafter, "GASB 67/68") fundamentally alter the financial reporting of pension liabilities, by (i) requiring pension liabilities to be estimated using a potentially lower discount rate (which increases estimated liabilities and any funding deficits), and (ii) mandating recognition of funding deficits (surpluses), which were previously only disclosed in footnotes, as a liability (asset) on governmental balance sheets. Although GASB 67/68 only changes financial reporting requirements and acknowledges specifically that funding decisions are outside its scope, we find, for a sample of 100 large state-administered plans, that governments increase pension contributions upon applying GASB 67/68. The increased funding response is primarily observed from governments expecting a larger dollar impact to applying GASB 67/68, and from governments facing more adverse economic or political consequences from financial statement recognition. Plans that increase funding are also more likely to have passed benefit cuts, suggesting that taxpayers and public employees share the costs. Overall, these responses suggest that governmental entities are willing to take actions with cash flow consequences to avoid recognizing large liabilities on-balance sheet; purely accounting changes, therefore, can have "real" effects on governmental pension policy.
\end{abstract}

Keywords: Public sector pensions, pension funding, valuation of pension liabilities, discount rates, Governmental Accounting Standards Board

*Corresponding author.

We thank participants at the University of Connecticut Risk Conference, the Temple University Fox School of Business' $100^{\text {th }}$ Anniversary Conference, the American Accounting Association's Governmental and Nonprofit Section Meeting, the Haskell \& White Corporate Reporting and Governance Conference, the Western Regional AAA Meeting, and seminar participants at UC Irvine, Norwegian School of Economics (NHH), and USC for useful feedback. All errors are ours alone. Comments are welcome. 


\section{Introduction}

Employer-sponsored pensions are a key pillar of retirement income security for workers in the United States (U.S.). Particularly within state and local governments — which employ $14 \%$ of the U.S. workforce - retirement plans have typically been defined-benefit (as opposed to definedcontribution) in nature, and $80 \%$ of state and local government employees rely solely on a definedbenefit (DB) plan for retirement income (Munnell and Soto 2007). ${ }^{1}$ As of December, 2018, state and local DB plans held $\$ 4.3$ trillion in assets to fund the retirement of 14.5 million active and 10.3 million retired employees of state and local government. ${ }^{2}$

Yet, despite the tremendous importance of public-sector pensions, many state and local DB plans have arrived at a state of near-crisis. ${ }^{3}$ In 2015, the largest state and local pension systems reported collective unfunded liabilities of $\$ 1.4$ trillion using valuation techniques from extant accounting standards. However, alternative valuation techniques that hew more closely to finance theory value the deficit at closer to $\$ 4$ trillion (Rauh 2017). While the largest state and local plans

\footnotetext{
${ }^{1}$ In a defined benefit (DB) plan, the employee's pension benefit is determined by a formula that incorporates years of service, salary, age at retirement, and other factors. In contrast, contributions in a defined contribution (DC) plan are paid into an individual account for each participant and are invested in funds of the participant's choice. The employer (employee) bears the investment risk and longevity risk in a DB (DC) plan.

${ }^{2}$ https://publicplansdata.org/quick-facts/national/, updated as of December 2018. DB plans are also important in the private (i.e., corporate) sector. One out of five private sector workers in the U.S. relies on a DB plan for retirement income, and about forty million private sector workers participate in the 26,000 DB plans sponsored by corporate employers and insured by the Pension Benefit Guaranty Corporation (Bureau of Labor Statistics National Compensation Survey: http://www.bls.gov/ncs/). However, defined-contribution (DC) plans are far more prevalent in the private sector today, with $64 \%$ of private-sector employees relying solely on a DC plan for retirement income. In contrast, only $14 \%$ of public-sector employees rely solely on a DC plan (Munnell and Soto 2007).

${ }^{3}$ See, e.g., Foltin, C., D. Flesher, G. Previts, and M. Stone. "State and Local Government Pensions at the Crossroads", CPA Journal (April 2017); O. Garret. "The disturbing trend that will end in a full-fledged pension crisis", Forbes (June 9, 2017); D. Grunfeld. "The looming pension crisis", The Rand Blog (November 8, 2017); M.W. Walsh. "An overhaul or a tweak for pensions", The New York Times (August 26, 2009); E. Ring. "The coming public pension apocalypse, and what to do about it", California Policy Center White Paper (May 16, 2016). Grunfeld quotes the then-treasurer of Orange County, who in as far back as 2005 warned that California's public-sector pensions were a "ticking timebomb", and California's Little Hoover Commission, which in 2011 advised the governor and State Legislature that "Unless aggressive reforms are implemented now, the problem will get far worse, forcing counties and cities to severely reduce services and lay off employees to meet pension obligations." Walsh quotes pensions commentator Jeremy Gold from 2009, describing California, Texas, and New Jersey's retirement systems as going "to hell in a handbasket".
} 
were funded to cover $72-74 \%$ of liabilities on average in fiscal years $2014-2018$, we find that funding levels vary widely, with about one-fifth of all plans less than $60 \%$ funded. The fiscal pressure from deteriorating pension funding is significant enough to have led to credit rating downgrades in states with critically underfunded pensions, such as Illinois, New Jersey, and Connecticut (S\&P State Global Market Intelligence 2017).

Pension commentators point to decades of overly generous benefit promises combined with persistent underfunding as having led plans to their current depleted state. ${ }^{4}$ Many states have historically contributed much less than their "Annual Required Contribution" (ARC), calculated per extant Governmental Accounting Standards Board (GASB) rules, which represents the employer's cost of retirement benefits earned by employees in the current year. ${ }^{5}$ Currently, proposals to relieve the funding burden by cutting benefits, eliminating cost-of-living-adjustments, and requiring employees to work longer or contribute more are being debated in courts across the U.S. (Brainard and Brown 2016). With these rapidly burgeoning moves to curtail or restructure benefits, the public retirement system in the U.S. has arrived at a crossroads. Decisions to fund pension plans (or not, as the case may be) carry enormous implications both for the beneficiaries who depend upon pension promises, and for the taxpayers who may be called upon to fulfill those promises, either through higher taxes or through cuts to public spending.

Two GASB pronouncements, both issued in June 2012, dramatically alter the accounting and reporting of pension expense and pension funding status for state and local governments, and aim to increase the transparency and comparability of pension commitments that governments across the U.S. have accrued over time. GASB Statement No. 67 Financial Reporting for Pension

\footnotetext{
${ }^{4}$ E.g., Andrew Biggs and Jason Richwine. Why Public Pensions Are So Rich. WSJ Opinion. January 4, 2012.

${ }^{5}$ In fiscal year 2015, only 13 of the 50 states contributed the full ARC or more, with some states such as New Jersey consistently contributing no more than $40 \%$ of the ARC for many years (S\&P Global Ratings 2016).
} 
Plans (applicable to pension plan reporting, effective for plan years starting after June 15, 2013) and GASB Statement No. 68 Accounting and Financial Reporting for Pensions (applicable to pension sponsor reporting, effective for fiscal years starting after June 15, 2014), collectively introduce changes that are twofold: (1) to measurement, and (2) to recognition.

With respect to measurement, previously, the pension obligation was valued by discounting projected future benefits at the long-term expected rate of return ("ERR") on pension assets. Now, the ERR can only be used to the extent that plan assets are projected to be sufficient to meet benefit payments, with a high-quality tax-exempt municipal bond rate applied to any balance of (unfunded) benefit payments remaining after the projected "depletion date". This results in a "blended" discount rate applied by any plan that is only partially funded. As governmental pension plans invest extensively in equities, their ERRs were typically much higher than high-quality municipal bond rates; the requirement to use a "blended" discount rate therefore lowers discount rates, resulting in larger estimates of pension liabilities and of funding deficits (Munnell, Aubry, Hurwitz, and Quinby 2011, Mortimer and Henderson 2014). With respect to recognition, any net pension liability determined by subtracting the fair value of pension assets from the pension obligation, as measured above, is to be recognized on the financial statements of state and local governments for the first time. Prior to these changes, GASB standards only required footnote disclosure of the unfunded liability.

The pension liabilities of state and local governments are so substantial that pension funding considerations shape public policy, budgets, and credit quality for many states (Kilroy 2015). As a result, the changes introduced by GASB $67 / 68$ have the potential to place economically substantial liabilities on the financial statements of state and local governments, as the new rules 
(1) potentially increase measured pension liabilities, and (2) require recognition of the underfunded liability on governmental balance sheets.

These changes, in turn, could heighten scrutiny of funding deficits from an array of stakeholders: (i) credit rating agencies, for whom pension deficits are a first-order consideration in the rating process; (ii) investors in municipal bond markets, who have incentives to monitor pension deficits because pensions are typically senior to general obligation bonds (Novy-Marx and Rauh 2012); and (iii) taxpayers, given that balanced budget requirements in most states necessitate higher taxes or cutbacks to other government expenditures in order to close pension deficits (Allen and Petacchi 2018; Costello, Petacchi, and Weber 2017). More scrutiny from these stakeholders raises the specter of increased financing costs and citizen oversight of pension management. Given these eventualities, it is plausible that governments respond in ways that minimize the negative impact to their reported financials, which begs the questions: do governments respond to GASB 67/68, and if so how? To the extent to which GASB 67/68 create negative economic consequences for sponsoring governments, do they attempt to minimize the impact on reported numbers? Answering these questions is the objective of our study.

We examine one outcome that is readily available for most plans: how much cash is contributed into plans following GASB 67/68 onset. Increasing contributions reduces the GASB 67/68 liability that needs to be recognized in multiple ways. For a plan that was underfunded before GASB 67/68 implementation (i.e., whose pension liability exceeds the fair value of plan assets), increasing contributions not only increases the fair value of plan assets but also-due to the mechanics of GASB 67/68 valuation—-decreases the estimate of the pension liability. ${ }^{6}$

\footnotetext{
${ }^{6}$ Higher contributions lower the estimated liability in more than one way-directly, by increasing the funded base that can be discounted at the (higher) ERR as opposed to the municipal bond rate; and indirectly, by helping to justify assuming a higher stream of expected future contributions when projecting the plan's depletion date, and so reducing the likelihood that the plan will be projected to run out of assets in the first place.
} 
We examine a sample of the 100 largest state plans, covered by the Public Pension Database of the Boston College Center for Retirement Research. For this sample, which covers about 80 (90) percent of public pension assets (membership) nationwide, we find that contributions increase significantly following GASB 67/68 implementation. After controlling for plan- and state-level determinants of contributions, we document an increase in total contributions of $3 \%$ of covered payroll (which translates to about $15 \%$ of the median and $30 \%$ of a standard deviation of total contributions). Importantly, this increase is driven by contributions from participating employers (which is eventually borne by taxpayers) rather than from the employees themselves.

Importantly, we find that the increase in contributions is concentrated in plans expecting a relatively large financial statement impact from GASB 67/68, i.e., relatively poorly-funded plans (for which the mechanics of GASB 67 valuation would predict a greater markup in the liability). The contribution response is also stronger from governments for which financial statement recognition of increased liabilities brings more adverse economic and political consequences; namely, governments accessing the debt markets, and governments with upcoming gubernatorial elections. In the subsample with a gubernatorial election upcoming in the subsequent year (where incumbents could have strong incentives to present a favorable picture of pension funding), we observe a striking increase in contributions to the tune of $12 \%$ of covered payroll.

While our baseline tests examine contribution increases, governments could also respond with other real actions that have negative consequences for public employees, such as cutting benefits. In additional analysis of benefit cuts over 2012-2015, we document that governments in poorer fiscal condition, which have lower ability to increase contributions, are more likely to cut benefits. Strikingly, we find that the plans that pass benefit cuts are also more likely to increase contributions post-GASB 67; this suggests that for the states that are tackling their pension 
problems, the burden is ultimately shared across taxpayers (through funding increases) and beneficiaries (through benefit cuts). A sharing of the burden may even be necessary for states to justify increased contributions to the voting public.

Our study offers the following contributions. First, we provide some of the first large-scale empirical evidence on the consequences of GASB 67/68, a pair of standards that were fiercely debated over an exposure period of six years, and which continue to be controversial. ${ }^{7}$ On one hand, recent work attempting to forecast the likely increase in liability measurements from GASB $67 / 68$ before the standards took effect estimates substantial increases in reported liabilities (Munnell, Aubry, Hurwitz, and Quinby 2012; Mortimer and Henderson 2014). ${ }^{8}$ On the other hand, compilations of state CAFR data post-GASB 67/68 implementation indicate that discount rates have shifted for only a small minority of plans (Moodys' Investor Service March 2015). ${ }^{9}$ Early forecasts of the impact of GASB 67/68, therefore, are seemingly incongruous with the eventual reality of its implementation. By demonstrating evidence of governments' responses that appear designed to mitigate the impact of GASB 67/68, our study provides a bridge between the seemingly incongruous early forecasts and eventual reality.

Our second contribution lies in demonstrating that even in the governmental setting, accounting standards that affect only the measurement and recognition of accruals-based assets,

\footnotetext{
${ }^{7}$ The GASB 67 (68) exposure drafts received 61 (651) comment letters from members of executive and legislative branches of government at state and local levels (offices of state Congressmen, governors, mayors, municipal councils, city managers, school districts, etc.), public employees, credit rating agencies, bond investors, and concerned citizens. ${ }^{8}$ Munnell, Aubry, Hurwitz, and Quinby (2012) forecast funded ratios for 126 plans in the Boston College Public Pension Database by applying GASB proposals when they were still in Exposure Draft stage, using highly granular plan-level parameters and assumptions to replicate the work of actuaries. They warn that "employers and plan administrators should be prepared for funded ratios reported in their financial statements to decline sharply under the new rules". Mortimer and Henderson (2014) develop a simpler methodology using readily-available data to estimate discount rates and funding ratios under the new standards, for a sample of one major plan from each state in 2010. Both sets of authors independently predict that average funding ratios would drop from around $75 \%$ to around $55 \%$, with average discount rates dropping from slightly below $8 \%$ to around $5 \%$.

${ }^{9}$ Rauh (2017), analyzing large state and local pension systems for 2015, notes: "Remarkably, many systems with very low funding ratios assert that assets, investment ratios, and future contributions will be sufficient so that their pension funds never run out of money, allowing them to continue to use the high rates under GASB 67."
} 
liabilities, and income, without direct effects on cash flows, can elicit managerial responses that affect cash flows. In other words, even in the governmental arena, accounting does have "real" effects. It is well understood that accounting standards have real effects in the context of publiclytraded firms, and a rich literature documents evidence of managers altering the terms of business transactions to achieve an accounting outcome or moderate the impact of an accounting change. ${ }^{10}$ This literature has concluded that many of these actions are motivated by managers' desire to preserve firm valuation or to preserve accounting-based inputs to (compensation or debt) contracts.

While the primacy of accounting numbers is well-established in the corporate context, whether governments are similarly motivated to alter real transactions to achieve accounting outcomes is not as clear. Governments have distinct organizational objectives; they report to a diverse array of stakeholders, some of whom have no equivalent in the for-profit world (citizens and elected representatives such as legislators) and some of whom do (creditors and pension beneficiaries); and their accounting reports are prepared by bureaucrats and overseen by elected or appointed officials whose incentives vary widely from corporate managers'. Allen and Petacchi (2018) find that states with weaker plans and stronger fiscal pressures are more likely to oppose the GASB's proposals during the exposure period, and that state governments opposing the GASB's proposals are also more likely to initiate benefit cuts as an early response to the exposure draft. These ex ante actions portend that state and local governments will not be passive bystanders with respect to the expected impact of GASB 67/68; our evidence expands on Allen and Petacchi's

\footnotetext{
${ }^{10}$ E.g., Horwitz and Kolodny (1980) find that firms reduce R\&D spending after SFAS 2 required R\&D to be expensed. Imhoff and Thomas (1988) find a substitution from capital leases to operating leases after SFAS 13 required capital leases to be recognized on-balance sheet. Bens and Monahan (2008) show that accounting rules requiring consolidation of variable interest entities reduce firms' willingness to sponsor these entities. Choudhary, Rajgopal, and Venkatachalam (2008) find that firms accelerate the vesting of employee stock options to avoid recognizing unvested option grants at fair value after SFAS 123R. Graham, Harvey and Rajgopal (2005) provide extensive survey evidence to the effect that managers take real actions to meet earnings goals.
} 
(2018) findings and confirms that governments are indeed willing to expend resources to minimize that impact. To the best of our knowledge, a recent paper by Khumawala, Ranasinghe, and Yan (2017), who document a reduction in U.S. municipalities' derivatives usage after an accounting rule change requiring balance sheet recognition of derivatives, is the only other work demonstrating that accounting recognition spurs real actions in a governmental setting.

Section 2 describes the public pensions landscape, the changes introduced by GASB 67/68, and lays out predictions. Section 3 describes the sample and research design. Section 4 discusses results on contributions, Section 5 explores benefit cuts, and Section 6 concludes.

\section{Institutional background and hypothesis development}

\subsection{State and local government pension plans in the U.S.}

The Census of Governments identifies about 2,670 retirement systems sponsored by a public-sector entity, i.e., state or local government. Munnell, Haverstick, Soto, and Aubry (2008) report from the 2002 Census that state- (as opposed to locally-) administered retirement systems, which cover general state employees and teachers, account for only $8 \%$ of all plans, but a majority of active participants $(88 \%)$ and assets $(82 \%)$. Local plans, which are many in number but small in size, are administered by municipalities, townships, counties, special districts, and school districts, and cover general municipal employees and often policemen and firefighters as well. ${ }^{11}$

Benefits under these DB plans are usually determined by multiplying the employee's final average salary by the number of years of service and a multiplier for each year of service, which is around 2\% in the public sector (Brainard 2007, US Department of Labor 2007). Governmental plans typically also provide cost-of-living adjustments (automatically, or on a frequent but ad-hoc basis), which are uncommon in private-sector (i.e., corporate-sponsored) plans (Munnell and Soto

\footnotetext{
${ }^{11}$ Structures vary widely from state to state - some states have a single system covering all employees (e.g., Maine and Hawaii) while others have over a hundred systems (e.g., Illinois and Michigan).
} 
2007). Also in contrast to corporate plans, governmental plans usually stipulate contributions from employees, in addition to contributions from employers and non-employer sources (e.g., the state).

Unlike private-sector plans, public-sector plans are not subject to the Employee Retirement Income Security Act (ERISA, 1974), and states vary widely in how plans are governed. Still, some commonalities exist: most public plans hold assets in trust and are governed by a board of trustees required to act solely in beneficiaries' interest. Trustees come from one of three groups: trustees who serve by virtue of their public office (e.g., a state treasurer who automatically serves on the board), trustees who are appointed by an elected official, and trustees elected by plan beneficiaries (Fitzpatrick and Monahan 2012). While almost all plans have annual funding (i.e., contribution) requirements, these requirements vary widely in how strictly they are enforced, and so the annual "required" contribution is not always contributed. ${ }^{12}$

\subsection{The erstwhile pension accounting framework and the shift brought about by GASB 67/68}

From 1994, the accounting for public plans was governed by GASB Statement No. 25 Financial Reporting for Defined Benefit Pension Plans and Note Disclosures for Defined Contribution Plans and GASB Statement No. 27 Accounting for Pensions by State and Local Governmental Employers. GASB 25 laid out the disclosures required in financial statements: plan assets, plan liabilities, required contributions from employers and employees, and the ratio of employer contributions made to required contributions, among others. GASB 27 focused on defining the employer's annual pension expense to be reported in the financial statement: this pension expense was equal to a figure known as the annual required contribution (“ARC"), defined

\footnotetext{
${ }^{12}$ E.g., the Ohio State Retirement System Board can sue employers for failure to pay contributions and can collect past due amounts, whereas the Illinois Teachers Retirement System (one of the most critically underfunded systems in the country) "has a long history of successfully fending off participant lawsuits" to increase contributions or make the required contributions (Fitzpatrick and Monahan 2012). Munnell, Haverstick, Aubry, and Golub-Sass (2008) report that many state and local governments are legally constrained in what they can contribute, as contribution rates are sometimes determined by statute and specify a rate smaller than that recommended by the actuaries. Other drivers of underfunding include state fiscal pressure and a lack of funding discipline.
} 
as the sum of normal cost (i.e., service cost) for that year and any payment required to amortize the unfunded liability over 30 years.

GASB 67 and 68 reflected a fundamental change in the GASB's approach towards pension accounting, along two dimensions. First, while GASB 25/27 did not intend to provide sufficient conditions for appropriate funding, the ARC had "become a de facto funding standard", which was "used to evaluate funding decisions of the employer" and had even "standardized the funding approaches of state and local governmental employers" (GASB 68 Basis for Conclusions, para 160). GASB 67/68, in contrast, created a "new hard-line division of accounting from funding" (Senta 2014). Second, these pronouncements shifted the primary focus of accounting from the income statement to the balance sheet. Under GASB 27, the focus was on what employers contributed each year relative to the ARC for that year; only if the cumulative ARCs exceed the cumulative amount contributed to date did a liability appear on the balance sheet to that extent. ${ }^{13}$ In contrast, GASB 68 assigns a plan's full unfunded liability (total pension liability minus fair value of plan assets) to the balance sheet of the employer sponsoring it, with a "smoothed" annual pension expense (calculated in a manner reminiscent of corporate pension expense under FASB rules) appearing on the income statement. ${ }^{14}$

\footnotetext{
${ }^{13}$ The shift in the recognition framework from GASB 27 to GASB 68, in this respect, mirrors the shift in FASB accounting rules for the private sector from SFAS 87 Employers' Accounting for Pensions to SFAS 158 Employers' Accounting for Defined Benefit Pensions and Other Postretirement Plans. SFAS 87 focused on defining a (smoothed) net periodic pension cost to be expensed on the sponsor's income statement, and a balance sheet liability was recognized only to the extent to which the employer's contributions into the plan fell short of the aforementioned pension cost. In contrast, SFAS 158 required recognition of the full unfunded liability (any excess of the projected benefit obligation over fair value of plan assets) on the sponsor's balance sheet.

${ }^{14}$ This change in approach was the culmination of refinements to the GASB's accounting theory, embodied in many Concepts Statements it released between GASB 25/27 issuance and GASB 67/68 issuance. Specifically, the GASB affirmed that a government employer's net pension liability meets the definition of a liability under Concepts Statement No 4 Elements of Financial Statements (issued 2007). GASB Statement No 34 Basic Financial Statements (issued 1999) also paved the way for pension accounting changes, by requiring governmental financial statements to be prepared using accrual basis and an economic resource measurement focus (BKD 2014). In the meantime, other standard-setting organizations (FASB, IASB) had also developed a pension accounting framework relying on markto-market principles, which could also have influenced the GASB's evolution in this regard.
} 
In addition to requiring recognition of the pension deficit or surplus, GASB 67/68 also change how the pension liability is measured. Whereas the pension liability was previously determined by discounting projected future benefits at a discount rate equal to the expected rate of return (ERR) on plan assets, GASB 67 now requires a "blended" discount rate to be applied in cases where the plan is projected to become insolvent at some point in the future.

To make this determination, the GASB specifies a multi-step process: (1) project future benefit payments to current employees based on current benefit terms; (2) project plan assets forward, taking into account expected inflows (contributions, plan asset returns) and outflows (benefit payments, expenses) associated with current members; and (3) if the assets so projected are sufficient to cover benefit payments for all periods, then use the ERR to discount those benefit payments; (4) but if the assets so projected are insufficient to cover benefit payments for all periods (i.e., if the plan is projected to run out of funds at some point), discount all benefit payments until that "projected depletion date" or "crossover point" using the ERR, and then discount all benefit payments after that date using a high-quality tax-exempt municipal bond rate; (5) the single equivalent discount rate that, when applied to all cash flows, produces the same total present value as the two-step discounting described above, is the "blended" discount rate. ${ }^{15}$ Appendix A provides

\footnotetext{
${ }^{15}$ The rationale for applying a muni-bond rate beyond the depletion date is that once the plan runs out of funds, the employer's projected sacrifice of resources takes on the nature of a conventional governmental liability (GASB 68 Basis for Conclusions Para 230), and so the applicable rate should reflect the characteristics of the rate used to discount other general unsecured liabilities of government (GASB 68 Basis for Conclusions Para 240). However, both components of the blended rate-the ERR and the muni-bond rate, have drawn extensive criticism from different quarters. Financial economists are almost universally opposed to the ERR as discount rate, as basing the valuation of a liability on the assets held to fund that liability violates basic tenets of finance theory, according to which streams of future cash flows should instead be discounted at a rate that reflects their risks, particularly their covariance with priced risks. As public pension promises are virtually certain to be paid, this suggests discounting at the risk-free rate (Novy-Marx and Rauh 2011). At the other conceptual extreme, other commentators criticized the tax-exempt munibond rate as unnecessary because funding policies would be adjusted over time to ensure that sufficient assets were available to pay benefits; or questioned its appropriateness for employers that are legally restricted from borrowing to fund pension plans; or argued for a taxable muni-bond rate, as pension obligation bonds are taxable borrowings (GASB 68 Basis for Conclusions, Para 233 \& 240).
} 
more detail on this procedure, while Appendix B comprehensively lists the changes in GASB $67 / 68 .^{16}$

\subsection{Potential implications of GASB 67/68: managerial responses}

The GASB identifies three potential user groups for governmental reporting: the bond market, citizens/voters, and elected representatives. Of these groups, investors in the bond market (and information intermediaries in that market, such as credit rating agencies and bond analysts) pay close attention to pension funding. Rating agencies themselves state that unfunded pension liabilities are a major driver of credit quality for states (Kilroy 2015), and deteriorating funding ratios are often quoted as the reason behind rating downgrades (e.g., S\&P Global Market Intelligence 2017 discussing downgrades of Connecticut, Illinois, Kansas, and New Jersey). In academic findings, Marks and Raman (1988) find that municipal debt costs are sensitive to unfunded accumulated liabilities; Martell, Kioko, and Moldogaziev (2013) find that state credit ratings are sensitive to aggregate pension funding ratios, and Novy-Marx and Rauh (2012) find that municipal bond spreads are sensitive to investment losses in state pension funds, all indicating that pension funding status and performance affect debt investors' perceptions of credit quality.

Many states also have balanced budget restrictions, which imply that taxes will have to be raised or public expenditures curtailed in order to close pension funding gaps (Costello, Petacchi,

\footnotetext{
${ }^{16}$ Discretion does exist in the GASB 67 estimation process, which can potentially be used to mitigate the impact of GASB 67/68. In the first step of estimation (projecting future benefit payments), benefits must include all automatic cost-of-living adjustments ("COLAs"), even any ad-hoc COLAs that are deemed "substantively automatic"; judgment has to be applied by the plan board, staff and auditors to evaluate COLAs and determine whether they are "substantively" automatic. In the second step (projecting plan assets), the projections include expected future contributions associated with current members, and if the plan has a statutory contribution basis or formal written funding policy, then "professional judgment" can be applied in projecting the most recent five-year history of contributions into the future. The GASB's decision to allow employers to take credit for future contributions raised numerous concerns of potential abuse, e.g., the AICPA's comment letter argued that "projected contributions are not based on objective criteria... employers could easily state that they are 'planning' for future contributions, even though the plan is significantly underfunded". A "formal written funding policy", moreover, can take many forms, and preGASB 67/68, many funding policies were extremely basic, e.g., "we contribute the ARC" (Goodhart and Reeb 2013).
} 
and Weber 2017); citizens/voters could also be concerned about pension deficits as a result. While there is not a lot of direct evidence in this regard, Rich and Zhang (2015) examine a sample of municipal pension plans, and document that funding ratios are stronger in municipalities that permit direct citizen participation in the legislative process (through petition initiatives) or when elected officials have recently faced recall attempts. These findings imply that the threat of citizen oversight affects pension funding decisions, in turn suggesting —at the least—-that pension funding is an outcome of interest for citizens.

Due to the strong interest of the bond market and the citizenry in public pension funding, we would expect elected representatives from both executive and legislative branches of government to also be concerned about pension reporting. Kido, Petacchi, and Weber (2012) document evidence consistent with public pension funding status being inflated ahead of gubernatorial re-election campaigns. Reported pension funding status, therefore, is a metric that public officials appear to believe is important.

Given that key stakeholders are concerned about pension funding, and that GASB 67/68 is expected to lower reported funding status, it is plausible that sponsoring governments have incentives to mitigate the "fallout" from GASB 67/68. Many commentators admit this possibility: Mortimer and Henderson (2014), for example, posit that governments with low funded ratios could be "tempted to manage reported pension values", either through the opportunistic use of discretion in estimating the crossover point and the GASB 68 pension liability, or through economic transactions and activities (i.e., "real" actions). A number of real actions are possible, which we could place along a spectrum by how they affect pension beneficiaries: at one end, governments wishing to reduce reported pension liabilities could close or freeze DB plans or downsize employee numbers, leaving beneficiaries worse off. Alternatively, they could retain their DB plans and/or 
employees but cut benefits. At the other end of the spectrum, governments could contribute more to their plans to shore up funding and so reduce the deficit reported on balance sheets; better funding improves benefit security for participants.

In this study, we focus on examining how annual contributions shift as a result of GASB 67/68. Of the varied ways in which governments can respond to contain the impact of GASB 67/68, we focus on contributions for two key reasons. First, at a conceptual level, the mechanics of GASB 68 liability valuation make contributions a heightened lever with which to reduce reported pension funding deficits, because increasing contributions not only increases the fair value of plan assets but also - in more ways than one — can reduce the estimated pension liability. It reduces the pension liability directly, by increasing the funded base that can be discounted at the (higher) ERR as opposed to the municipal bond rate; and also indirectly, by helping to justify assuming a higher stream of expected future contributions when projecting the plan's depletion date. For plans with a formal funding policy that are allowed to apply judgment in projecting historical contributions into the future, higher current contributions should help to justify projections of higher future contributions; and for plans lacking a formal funding policy, higher current contributions increase the five-year-average of most recent contributions that serves as the maximum projected future contribution. Higher projected contributions, in turn, reduce the likelihood that the plan will be projected to run out of assets in the first place. Second, at a more practical level, contributions are readily observable for all plans and can be changed in response to the standards. As higher contributions result in lower reported pension deficits, we expect that contributions to public pensions will increase post-GASB $67 / 68 .{ }^{17}$

\footnotetext{
${ }^{17}$ Anecdotally, we observe multiple instances of governments acting to shore up pension funding around GASB 67/68 passage and implementation. For example, California enacted legislation in June 2014 with a view to fully funding the CALSTRS by 2046 through increases in state, employer, and employee contributions; the State of CA increased its contributions to CALSTRS starting in the fourth quarter of FY 2013-2014 as a result. The State of CA also made
} 
Our prediction that GASB 67/68 will elicit real actions is, however, not straightforward; it hinges on some assumptions. The first of these assumptions is that financial statement measurement and recognition matter, in the governmental context. Note that none of the GASB 67/68 provisions alter the underlying fundamentals of what is actually owed to pensioners: to quote Munnell et al. (2012), "\$1,000 owed to a retired teacher in ten years under current standards will remain $\$ 1,000$ owed in ten years under the new standards". Estimates of the pension liability developed by discounting those benefits at the ERR were disclosed in governments' financial statements since long before the advent of GASB 67/68. The new standards only require those benefits to be discounted at a potentially lower rate, leading to a higher single number representing what is owed in present value terms, and in addition place that number (net of pension assets) on the government-wide balance sheet. If bond investors/voters were already discounting benefits at rates lower than the ERR, and were also impounding the resulting higher liabilities into their decision process, then financial statement recognition of those higher liabilities need not, by itself, bring any economic consequences, or elicit responses to minimize those consequences.

Whether financial statement measurement and recognition indeed matter (i.e., carry economic consequences) in the governmental setting is not clear. In the pension setting in particular, extant anecdotal and empirical evidence presents a very mixed picture. On one hand, there is evidence to suggest that credit rating agencies were already discounting pension benefits at rates lower than the ERR. For example, Moodys' already used a high-grade corporate bond index to discount governmental pension liabilities (akin to FASB discount rate requirements per SFAS 87); it announced not only that its methodology would remain unchanged but also that it did

a one-time contribution of $\$ 6 \mathrm{bn}$ to reduce CALPERS' deficit in 2017. The Alaska State Legislature appropriated \$3bn from the state's oil reserves to fund state pensions in 2014. When collecting data on benefit reforms undertaken by states (Section 5), we note that at least twelve states legislate increases in employer contributions in recent years. 
not expect most ratings to change after GASB 67/68, as did S\&P (Moodys' Investor Service 2014, S\&P Ratings Services 2013). ${ }^{18}$ Hallman and Khurana (2015) empirically confirm the notion that rating agencies impound higher liabilities than those previously reported, by re-estimating state pension liabilities at a high-quality municipal bond discount rate; they find that the resulting adjustments are associated with credit ratings and interest costs, over and above the unfunded accrued pension liability reported in CAFRs under pre-GASB 67/68 rules. On the other hand, though, Allen and Petacchi (2018) report that the exposure drafts for GASB 67/68 elicited an overwhelming response, with a good proportion of respondents arguing that the measurement and recognition proposals would create adverse economic consequences, e.g., prompting governments to cut benefits or even close plans. In a study of over 200 local governments from Michigan and Pennsylvania, Vermeer, Styles, and Patton (2012) document that one-third of those governments did not even report the unfunded pension liability on their CAFRs under the GASB 27 regime, which is prima facie hard to reconcile with credit rating agencies' contention that GASB 67/68 will not change their ratings. Therefore, ex ante, it is not clear whether measurement and recognition from GASB 67/68 will alter key stakeholders' decision processes in this setting.

The second assumption is that these economic consequences actually incentivize decisionmakers in the government setting to respond. In the corporate setting, poor reported performance leads to questions from analysts, increases scrutiny from institutional investors and boards of directors, lowers valuations with consequent impacts on managers' compensation packages, and can even lead to the manager being fired. In the governmental setting, even if borrowing costs should increase, it is not clear whether the bureaucrats, elected officials, and legislators who set

\footnotetext{
${ }^{18}$ However, municipal bond yields could still show variation independent of credit ratings (Gore 2004): first, many municipal bond issues are unrated; and second, even for rated issues, the ratings alone are not sufficient for investors to determine risk. This is because the ratings only provide a range for the probability of default, not the probability of recovery, and ratings agencies do not assess the liquidity of underlying assets.
} 
pension policy face consequences. Some indirect evidence exists in this regard: Rich and Zhang's (2015) findings that pension funding is stronger when elected officials have recently faced recall attempts suggests that poor pension funding brings a greater threat of recall; as does Kido, Petacchi, and Weber's (2012) findings that reported pension funding is inflated ahead of gubernatorial elections. ${ }^{19}$ A stream of work in public administration documents that fiscal performance affects the turnover of top executives in local government (Feiock, Clingermayer, Stream, McCabe, and Ahmed 2001; McCabe et al 2008). Indirect impacts could also exist, through debt costs as a channel - if borrowing costs go up, property taxes may go up, with adverse consequences for government officials' re-election prospects (Gore, Sachs, and Trzcinka 2004). However, public policy decisions often do not take effect immediately—policies enacted in one administration may only take effect in the next. Politicians frequently shift blame by claiming to have "inherited" policy problems from their predecessors (McGregor 2017, Washington Post). Thus, it is not clear whether the economic consequences of GASB $67 / 68$ will motivate decisionmakers to respond.

The third assumption is that government officials actually have the discretion to take actions-real actions or otherwise-that can minimize the impact of GASB 67/68, and that those actions will be observable in the time that has elapsed since the standards went into effect. Funding increases could take time to effect as budget priorities have to be reset, particularly in states facing balanced-budget mandates. Legislation has to be passed or amended in states where contributions are set by statute. It is possible that decision-makers are able to exercise discretion in "accrual" estimation of the crossover point for funding levels but are unable to undertake "real" actions, in

\footnotetext{
${ }^{19}$ Rich and Zhang (2014) also document, more broadly, that municipal finance directors are more likely to experience job loss when their municipalities disclose accounting restatements; however, restatements could indicate serious fiscal mismanagement or malfeasance on a scale that does not generalize to our setting.
} 
which case we would not find support for our hypothesis. For all these reasons, it is an empirical question whether contributions increase after GASB 67/68.

\subsection{Cross-sectional differences in the response to GASB $67 / 68$}

We do not expect similar responses from all governments, firstly because the actual dollar impact from GASB 67/68 varies. For plans that are not projected to run out of assets even under the most conservative scenarios, the "blended" discount rate applicable under GASB 67/68 will continue to be the same as the ERR. The measurement of the pension liability for these plans, therefore, need not change; the main impact will be that this liability, previously only disclosed in footnotes, will now be recognized on the government-wide statement of net position (a "recognition versus disclosure" shift). For plans that are projected to run out of assets, however, the discount rate will shift downwards, resulting in a larger reported pension liability-a measurement effect in addition to a recognition effect. Moreover, some plans will experience a greater upswing in the estimated pension liability than others. Finally, the pension liability will form a more economically significant part of the government-wide balance sheet for some governments than for others. To the extent to which there is a response to mitigate the impact of GASB 67/68, this response should intuitively be stronger from governments facing a larger financial statement impact from GASB 67/68.

Second, the financial statement recognition of one dollar of pension liabilities could generate more adverse economic consequences for some governments (or officials) than for others. To the extent to which bond market perceptions are actually affected by GASB 67/68 measurement and recognition, increased liabilities reported on balance sheets may trigger credit rating downgrades, increase the cost of debt financing, or raise the specter of covenant violation and renegotiation costs. We expect that these economic consequences will be more severe for 
governments that rely more heavily on debt financing (Allen and Petacchi 2018). Accordingly, we

predict that these governments have stronger incentives to mitigate the impact of GASB $67 / 68 .{ }^{20}$

Third, the financial statement recognition of one dollar of pension liabilities could have greater political ramifications for some elected officials. The consequences of recognizing increased pension deficits could be particularly adverse for governors facing re-election, as elections are likely to heighten scrutiny on the state's fiscal health, credit ratings, ability to borrow, and how these have evolved under the governor's watch. ${ }^{21}$ Motivated by Kido, Petacchi, and Weber (2012)'s findings that pension funding status is inflated to present a more favorable picture of funding ahead of gubernatorial elections, we predict that real actions in the form of funding increases - if any are undertaken, are more likely ahead of gubernatorial elections.

\section{Sample and Research Design}

\subsection{Sample selection}

We obtain plan-level data from the Boston College Public Plans Database (PPD) for 2001 to 2016. The PPD contains data for 170 public pension plans: 114 of the largest state-administered plans from all U.S. states and 56 of the largest locally-administered plans, which together comprise 95 percent of public pension assets nationwide, with approximately 82\% (13\%) from state (local) plans. As local plans vary widely in their governance structure and the political and regulatory

\footnotetext{
${ }^{20}$ As a caveat, governments that rely heavily on debt financing may not have the ability to reduce the GASB 67/68 liability by increasing contributions. These governments could attempt to reduce the GASB 67/68 liability through other actions: cutting benefits, as Allen and Petacchi (2018) document, or applying accounting discretion to lower the reported GASB 67/68 liability.

${ }^{21}$ Newly elected Governors of three states—New Jersey (Philip Murphy (D), 2017), Illinois (J.B. Pritzker (D), 2018) and Connecticut (Ned Lamont (D), 2018) made finding sustainable solutions to pension funding a key part of their campaign platform (https://www.bloomberg.com/opinion/articles/2019-02-25/three-new-governors-face-three-oldpension-disasters). Even for Governors not seeking re-election, state fiscal health and credit ratings remain important to evaluating their performance in office: e.g., the fact that New Jersey had seven rating downgrades during Chris Christie's term as Governor was a critique raised often during Gov. Christie's campaign for U.S. President in 2016. (https://www.politifact.com/punditfact/statements/2014/nov/09/greta-van-susteren/claim-new-jersey-has-had-7credit-downgrades-chris/).
} 
environment they operate in, we restrict our sample to state plans so as to preserve a greater degree of homogeneity. Of the 114 state-administered plans on the PPD, our final sample is 100 statesponsored plans with nonmissing values for all our variables of interest, described later. The PPD is updated each spring from data available in the most recent Comprehensive Annual Financial Reports (CAFRs) and Actuarial Valuations. Table 1 describes our variables of interest, many of which we obtain directly from the PPD.

\subsection{Empirical specification}

We estimate the impact of GASB 67/68 on contributions with the following model:

Contributions $=\beta_{0}+\beta_{1}$ POST-GASB67 $+\beta_{2}$ Funding Ratio (Prior-Year) $+\beta_{3} \%$ Required Contributions Paid $+\beta_{4}$ Plan Covers Teachers $+\beta_{5}$ Accrued Liability $/$ Tax Revenue $+\beta_{6}$ Unfunded Accrued Liability / Tax Revenue $+\beta_{7}$ Exp_Minus_Rev $+\beta_{8}$ TTLBAL Ratio $+\beta_{9}$ Per Capita Shortterm Debt Issued $+\beta_{10}$ Per Capita Growth in Gross State Product $+\beta_{11}$ Balanced Budget $+\beta_{12}$ Union Membership $+\beta_{13}$ Election $+\beta_{14}$ Corruption $+\beta_{15}$ Constitution $+\beta_{16}$ Gratuity + YearQuarter Fixed Effects

Equation (1)

The dependent variable Contributions is cash contributions for the fiscal year, scaled by prior-year covered payroll. We estimate the model separately for contributions from various sources: (i) employees, (ii) employers, and (iii) total contributions from all sources (employees + employers + state). To the extent to which total contributions do increase in response to GASB $67 / 68$, the increase could come from any of these sources; notice however that if employee contributions increase (presumably because higher contributions are mandated), this would be tantamount to a benefit cut, on a net basis, from employees' perspective. On the other hand, if contributions from employers and the state were to increase, this implies a greater ultimate burden being placed on taxpayers.

Our independent variable of interest is the POST-GASB67 indicator, which is set to one for all fiscal years applying GASB 67; i.e., fiscal years beginning after June 15, 2013. While GASB 
67 (which introduced the new pension liability measurement) is applicable to plan-years beginning after June 15, 2013 and GASB 68 (which mandated financial statement recognition) is applicable to fiscal years beginning after June 14, 2014, we use the earlier of the two effective dates as our cutoff, as both standards were issued together and the revised pension liability estimates must be produced as of the effective date of GASB 67.

Our specification relies on time-series differences in contributions between pre- and postGASB 67 periods to infer the impact of the GASB rule changes, in the absence of a feasible control group of plans that remain unaffected by GASB rules. ${ }^{22}$ As a result, contemporaneous events or macroeconomic shifts that affect contributions for the broad cross-section of plans have the potential to confound our results. In order to more confidently attribute any shifts we observe to GASB 67/68, we make the following research design choices/observations.

First, we include a number of controls for the effect of contemporaneous events or macroeconomic factors that can drive contribution shifts. As state governors, legislatures, and pension boards have to work in concert to implement funding increases, we control for financial conditions as well as political institutions and environment. We start with fixed-effects for the

\footnotetext{
${ }^{22} \mathrm{We}$ considered a number of potential control groups but concluded that each would not be appropriate for varying reasons. First, we considered foreign governmental plans, similar to Andonov, Bauer, and Cremers (2017). However, these plans are subject to an entirely different regulatory framework, political considerations, and macroeconomic drivers of year-to-year funding decisions. Second, we considered U.S. corporate plans, which are also subject to an entirely different regulatory framework (e.g., the Employee Retirement Income Security Act of 1974, which imposes a system of mandatory contributions on sponsors). We concluded that in our setting, it was unclear what, if any, omitted variable concerns would be alleviated by matching to U.S. corporate plans. Third, we investigated the possibility of matching to U.S. state and local government plans that were exempt from GASB 67/68, as these new standards only apply to pension plans administered through trusts or equivalent arrangements. A separate standard, GASB 73 Accounting and Financial Reporting for Pensions and Related Assets that are Not within the Scope of GASB Statement 68, and Amendments to Certain Provisions of GASB Statements 67 and 68, covers these plans, and is applicable for plan years beginning after June 15, 2016. However, plans that are so exempt from GASB 67-68 typically lack dedicated assets (Chmielewski 2016), which makes them inappropriate as a control group for examining funding decisions. Finally, we considered matching to U.S. state and local plans that choose not to report under GASB rules, as some states have still not mandated GAAP for state and local government reporting (GASB 2008). However, (1) this sample is likely to be strongly self-selected, as we surmise that governments that access debt markets and desire credit ratings are highly likely to choose to report under GAAP even if not mandated to do so; (2) at a practical level, for those entities that chose not to apply GAAP, we encountered considerable difficulty in accessing CAFRs and compiling the variables required to estimate the empirical models.
} 
calendar quarter and year of the fiscal year (e.g., a dummy variable set equal to one for fiscal years ending in Q1 - Jan, Feb, or Mar of 2013; a dummy variable set equal to one for fiscal years ending in Q2-April, May, June of 2013; and so on). We control for plan-specific drivers of contribution policy: Funding Ratio (Prior Year) (measured as prior-year plan assets scaled by prior-year plan liabilities), as poorly-funded plans tend to contribute less, but may face pressures to contribute more so as to close funding gaps; and \% Required Contributions Paid (measured as the three-year average of the ratio of actual contributions to required contributions), to control for any historical funding patterns and policies, as governments that typically have met their required contributions could be more committed to funding their pension plans. Plan Covers Teachers (an indicator set to one for teachers' plans), captures the more generous benefits that teachers accrue by virtue of their longer tenure and higher earnings (Munnell, Haverstick, and Aubry 2008).

Transitioning from plan- to state-level controls, Accrued Liability / Tax Revenue (the accrued pension liability scaled by current-year tax revenues) bridges these two categories by capturing plan size relative to the state's ability to generate taxes; this is a key measure of how economically significant the pension liability is to that state's financial statements. On one hand, states might contribute more to larger plans, as they are more visible; on the other hand, state resources are likely to be constrained when servicing larger plans. We separately incorporate the pension deficit relative to tax revenues (Unfunded Accrued Liability / Tax Revenue).

At the state-level, we control for the state's financial condition along many dimensions. Following Naughton, Petacchi, and Weber (2015), we measure state financial constraints with the per capita difference between final expenditures and final revenues in the general fund and then add back any midyear spending cuts or tax changes (Exp_Minus_Rev). If Exp_Minus_Rev is positive (negative), the state is running a deficit (surplus). In contrast to this "flow" measure, 
TTLBAL Ratio (measured as ratio of total balances to expenditures in the general fund, where total balances are general fund balances plus budget stabilization or "rainy day" fund balances) serves as more of a "stock" measure of financial constraints. Governments with low rainy-day fund balances have a smaller cushion of reserves to draw upon when faced with an unexpected demand for resources. Per Capita Short-Term Debt Issued (short-term debt issued during the year scaled by the state population) captures the state's reliance on the debt market. Per Capita Growth in Gross State Product captures the overall performance of the state economy; states tend to contribute more to pensions in times of prosperity.

To control for the state's political and legal institutions and environment, we incorporate Balanced Budget (measured as the value from an index produced by the Advisory Commission on Intergovernmental Relations, ACIR 1987) ranging from 0 to 10 , with higher values for states with more rigorous balanced budget provisions, which likely have less discretion to increase contributions. Union Membership (the percentage of state public sector employees who are members of a labor union or similar employee association) is an important aspect of the political environment, as powerful unions could pressure states to contribute more to pension plans; as is Election (an indicator set to one if the state has a gubernatorial election in the current year), to control for governors' incentives to report a favorable picture of pension health. We also incorporate Corruption, an indicator set to one for above-median federal convictions per capita of local, state, and federal officials from that state for public corruption in that year.

One final set of controls for state-level legal institutions relates to the legal protection of pension promises, which varies significantly across states. At one end of the spectrum are states that have explicit language in their constitution prohibiting benefit reductions for current employees (to varying levels-sometimes only for past accruals, and sometimes for future accruals 
as well), which provides the strongest level of protection. At the other end of the spectrum are states that treat pension benefits as a "gratuity" from the employer, which amounts to virtually no legal protection. In between the two extremes are states applying contract law or a property rights approach to provide varying levels of protection for past and future pension accruals. We incorporate two indicators-Constitution and Gratuity, respectively, to flag states with the strongest protection (i.e., constitutional-level) and the weakest protection (gratuity approach) (Munnell and Quinby 2012). Table 1 defines all variables.

In addition to employing these controls for other drivers of contribution increases, we rely on cross-sectional partitions to more sharply identify the impact of GASB 67/68. We are interested not only in whether contributions increase on average for the sample of plans we examine, but also in whether the upswing is stronger for governments more affected by GASB 67/68's reporting changes. As described in Section 2.4, we expect any response to GASB 67/68 to be stronger from governments for which (1) the financial statement impact of GASB 67/68 is larger; and for which the financial statement recognition of pension liabilities engenders (2) more adverse economic consequences; and (3) more adverse political consequences.

\section{Empirical Results on Pension Contributions}

\subsection{Descriptive statistics of key variables}

In Table 2, we describe the variables used in multivariate tests, with Panel A (B) describing the two event years pre-GASB 67 (post-GASB 67) respectively. All variables are winsorized at the $1^{\text {st }}$ and $99^{\text {th }}$ percentiles. We define fiscal years using the cutoff for the effective date of GASB 67, which is effective for plan-years beginning after June 15, 2013. Hence, GASB 67 is first applicable to plan-years ending on June 15, 2014 to June 14, 2015, which we denote as year $t 0$. Next, we define fiscal year $t$ - 1 as plan-years ending on June 15, 2013 to June 14, 2014, and so on. 
In our tests, we use only the two years immediately preceding GASB 67 (i.e., event years $t$ - 2 and $t-1$, described in Panel A) and the two years immediately following GASB 67 (i.e., event years $t 0$ and $t+1$, described in Panel B), to mitigate potential confounding effects from unrelated events introduced by a longer time series.

In Panels $\mathrm{A}$ and $\mathrm{B}$, we first describe reported pension assets and pension liabilities, respectively (in millions of dollars). Pension assets and liabilities are clearly economically significant, with mean (median) assets of \$22.3 (\$11.7) billion in the pre-period, shifting to $\$ 24.3$ (\$13.5) billion in the post-period. Pension liabilities are predictably even larger, with mean (median) liabilities of $\$ 30.9$ (\$17) billion in the pre-period and $\$ 33.2$ (\$18.2) billion in the postperiod. In any given year, the means are close to double the medians, indicating the presence of some very large plans in our sample.

Unlike the raw (i.e., unscaled) pension assets and liabilities, the mean and median (lagged) funding ratios are quite similar to each other. Funding ratios start at $73.4 \%$ (72.2\%) of the liability in the pre-period, and remain steady at 72.9\% (72.8\%) post-GASB 67/68; we have no prior on how funded ratios might evolve, as real actions undertaken by governments could counteract GASB $67 / 68$ 's increase to measured liabilities. In both periods, though, the variation in funding ratios is substantial, with the $25^{\text {th }}$ percentile just above $60 \%$ funding and the $75^{\text {th }}$ percentile at almost $85 \%$ funding. In the pre-period $88 \%(93 \%)$ of required contributions are paid, with $89 \%(96 \%)$ paid in the post-period. The accrued liability remains steady at about $1.8 \mathrm{x}(1.3 \mathrm{x})$ state tax revenues.

Moving to state finances, states are generally running deficits of $\$ 12$ (\$9) per capita in the pre-period, worsening to deficits of \$20 (\$16) per capita in the post-period; state reserves, in the form of general fund or rainy-day balances, increase slightly from $13 \%(6 \%)$ to $14 \%(8 \%)$. The percentage growth in per capita GSP inches up from $0.65 \%(0.80 \%)$ to $1.48 \%(1.5 \%)$. So, the 
overall fiscal condition of states does not appear to have shifted significantly between the pre- and post-periods.

On average, $11 \%$ of public sector employees are represented by unions, and while only $14 \%$ of pre-period observations are from a gubernatorial election year, $38 \%$ of the post-period observations are. $16 \%$ of plans are from states offering constitutional protection for pension benefits; $10 \%$ from states treating pension benefits as a gratuity.

When constructing the dependent variable measures of contributions, we scale by prioryear covered payroll. As we expect contributions to increase after GASB 67, it is important to rule out the alternative explanation that the scaled contribution variables increase due to reductions in the scalar. From Table 2, covered payroll is not decreasing over time, but rather, remains steady across both periods. We also scale contributions by lagged (i.e., prior-year) covered payroll to further mitigate confounding effects from contemporaneous covered payroll.

Employee contributions remain steady, from a mean (median) of $6 \%(7 \%)$ of covered payroll in the pre-period to $7 \%(7 \%)$ in the post-period; employer contributions increase from $14 \%$ (12\%) to $15 \%$ (13\%) of covered payroll; and contributions from employers and state increase from $15 \%(12 \%)$ to $17 \%(14 \%)$ of covered payroll. Overall, mean (median) total contributions increase by about $3 \%$ of covered payroll from $22 \%(20 \%)$ to $25 \%$ (23\%), with much of the increase seemingly from non-employee sources, i.e., participating employers and state governments.

\subsection{Do contributions increase after GASB 67?}

We now turn to multivariate tests to examine whether contributions increase around GASB 67/68 implementation. Table 3 presents results of estimating Eq. (1) with contributions from the key sources-employee, employer, and total-as dependent variables in Panel A, B, and C respectively. Broadly consistent with univariate patterns, POST-GASB67 is insignificant in Panel 
A (employee contributions), but positive and strongly significant in Panel B (employer contributions) and Panel C (total contributions, comprising employee + employer + state contributions). There is no evidence, hence, of increased employee contributions (which would be tantamount to a benefit cut from employees' perspective) over the timeframe we examine. Rather, the increased funding burden appears to be placed on participating employers to the largest extent.

The coefficient estimates in Panel B (C) indicate an increase in employer (total) contributions of $2.8 \%$ (3\%) of covered payroll in the two years subsequent to GASB 67 implementation relative to the two years prior, after controlling for plan- and state-level determinants of contributions. A shift in employer contributions of $2.8 \%$ of covered payroll is equivalent to an increase of $20 \%$ (23\%) relative to the mean (median) [and $31 \%$ relative to the standard deviation] of pre-period employer contributions. For total contributions, the increase by $3 \%$ of covered payroll translates into $14 \%$ (15\%) of mean (median) [and 30\% of the standard deviation] of pre-period total contributions. These shifts hence appear economically significant.

While none of the plan- or state-level controls are significant in the employee contributions model, many are in the employer and total contributions models, indicating that employer and state contributions are more responsive to changes in plan and state fiscal conditions. This is an intuitive finding, given that mandated increases in employee contributions are tantamount to a benefit cut, and take time and effort to negotiate. Plans with weaker prior-year funding ratios receive more contributions from employers and in total, consistent with stronger pressures to fund in these cases. \% Required Contributions Paid is highly significant in the positive direction for both employer and total contributions, indicating persistence in funding practices. Contributions are surprisingly lower for teachers' plans, but we conjecture that covered payroll could be higher for teachers. 
When the unfunded liability is larger relative to state tax revenues (Unfunded Accrued Liability / Tax Revenue), contributions are lower, possibly indicating lower ability from the state to fund.

With state-level controls, TTLBAL Ratio shows an interesting pattern across contribution sources. Stronger state reserves associate with lower employer contributions but (weakly) higher total contributions, consistent with state governments contributing more and requiring less from participating employers when the state has a stronger fiscal cushion. With political and legal institutions, more rigorous Balanced Budget provisions associate with lower total contributions, likely driven by lower state contributions. ${ }^{24}$

We find striking effects on the indicators capturing legal protection for pension promises. States offering the weakest protection (the gratuity approach) make significantly lower contributions from non-employee sources; employer (total) contributions are lower by $6.3 \%$ (5.5\%) of covered payroll. In contrast, states offering constitutional protection for benefits have higher total contributions to the tune of $4.5 \%$ of covered payroll, albeit significant only at $10.5 \% .{ }^{25}$

\subsection{Cross-sectional variation in the post-GASB 67 shift in contributions}

\subsubsection{Expected magnitude of financial statement impact}

Table 4 presents Eq. (1), with total contributions as the dependent variable, estimated separately within subsamples created by the expected magnitude of GASB 67's impact on financial statements. To capture the magnitude of impact, we partition on the plan's funding ratio (Funding Ratio (Prior Year)), measured at year $t$-2 relative to GASB 67 adoption.

Panel A (B) tabulates estimations within the well-funded (poorly funded) subsample. The mean (median) funding ratio within Panel A is $85 \%$ (83\%), in contrast to 59\% (61\%) within Panel

\footnotetext{
${ }^{24}$ When rerunning Eq. (1) on state-only contributions, we find a strongly significant positive coefficient on TTLBAL Ratio (as we would expect) and on Union Membership.

${ }^{25}$ In additional tests breaking down constitutional protections further, we find a positive and significant effect from states that offer constitutional protection to past and future pension accruals (i.e., the strongest level of protection).
} 
B. Within well-funded plans (Panel A), the coefficient on POST-GASB67 is positive but insignificant; within poorly-funded plans (Panel B), however, we observe a positive and significant coefficient on POST-GASB67, with a 5.5\% (of covered payroll) increase in total contributions on average.

\subsubsection{Economic and political consequences of financial statement recognition}

While the dollar impact from GASB 67/68 on the financial statements of state governments varies widely, a dollar recognized on-balance sheet could itself result in very different economic and political consequences across governments. We expect stronger responses from governments facing potentially more adverse economic and political consequences to recognition.

In Table 5, we present Eq. (1) estimated separately within subsamples for which we expect the economic consequences of recognition to vary. To the extent to which the changes from GASB 67/68 affect debt investors' perceptions adversely, we would expect a stronger response from governments that rely more on the debt market. We measure debt market reliance with short-term debt issued in the year (Per Capital Short-Term Debt Issued); to form two approximately equalsized subgroups, we assign states issuing less (more) than $\$ 0.03$ of short-term debt per capita to the low (high) subgroup in Panel A (B). Consistent with expectation, we find an insignificant effect on POST-GASB67 within low-debt-issuance governments (Panel A), but a positive and significant effect within high-debt-issuance governments (Panel B), with the coefficient on POSTGASB67 in Panel B indicating a 4.1\% (of covered payroll) increase in contributions. ${ }^{26}$

In Table 6 we partition on political consequences, captured by whether the state has a gubernatorial election next year (Election). The results are striking: for the subsample without a

\footnotetext{
${ }^{26}$ These results also carry an alternative implication: contributions are higher for the high-debt-issuance group because sponsors are borrowing to fund pensions. This interpretation is different from that implied by our prediction, but is still interesting because it suggests that post-GASB 67, closing pension funding gaps is important enough to merit additional borrowing, particularly given that debt issuance is a politically-fraught process for state/local governments.
} 
gubernatorial election in the upcoming year (Panel A), we observe a negative and insignificant coefficient on POST-GASB67; for the states that do have an election upcoming (roughly onequarter of the total sample), we observe a highly significant increase in total contributions, to the tune of almost $12 \%$ of covered payroll — the largest contribution response we isolate so far. ${ }^{27}$

Tables 5-6 in combination paint a picture of contribution responses being driven by governments that are highly concerned with avoiding the negative debt market and election-year consequences of liability recognition.

\section{Other Real Actions in Response to GASB 67/68: An Exploration of Benefit Cuts}

While boosting contributions is a key "real" action that can mitigate the impact of GASB $67 / 68$, it is but one of a portfolio of possible real actions, as we discuss in Section 2.3. While higher funding improves benefit security for plan participants, the changes wrought by GASB 67/68 could motivate some governments to respond with a very different action, one that could potentially leave plan participants worse off: reduce benefits. Indeed, many states and localities have moved (or plan) to cut benefits along many dimensions. Moreover, these two types of responses (increasing funding versus cutting benefits) could interact in multiple ways: in one scenario, these actions could function essentially as substitutes_-some states may be more inclined to reduce benefits while others may be more inclined to improve funding; in another scenario, these actions could go together: some governments could be serious about addressing pension deficits, and renegotiate benefits packages while also mandating increased contributions from various sources

\footnotetext{
${ }^{27}$ We observe interesting patterns on balanced budget restrictions across the partitions, which can inform on states' relative priorities. First, from Table 4, Panel B (lower Funding Ratio), Balanced Budget is negative and significant while insignificant in the high Funding Ratio subsample; i.e., only when pension status is poor do balanced-budget restrictions appear to bind. While this is intuitive, even more interesting is Table 6, where Balanced Budget is negative and significant only when there is no upcoming election. In other words, balanced-budget constraints are binding only when there are no election-related pressures to improve pension funding, suggesting that pension funding becomes a lesser priority in non-election years.
} 
(employees, participating employers, and the state). In this section, we attempt to provide some descriptive evidence on these questions.

Benefit cuts are intrinsically more difficult to model than contributions, for many reasons. First, while contributions are made every year, and have many well-understood determinants, benefit cuts are more one-off (or at the minimum, sporadic) events. Therefore, we lack a strong understanding of why (and when) some governments find themselves at a "tipping point" when they decide that current benefit levels are unsustainable. Second, benefits can be reduced in myriad ways (e.g., requiring employees to contribute more or work longer for the same benefit, or applying a more conservative accrual formula, to name a few) and for many classes of employees (new hires, active employees, or retirees), and we lack the disclosures necessary to estimate the actual economic significance of each change on expected levels of benefits or funding. We make many research design choices as a result, and so our analysis is exploratory and descriptive.

Unlike our analysis of contributions, which has been at plan-year level, we analyze benefit cuts at the plan-level. We make this choice for a few reasons: first, contributions occur every year, allowing us to detect an on-average change over an event threshold (i.e., GASB 67 effective date), but benefit cuts are one-off events. Second, a benefit cut is not an "event" that applies only to the year of its passage; rather, it effects a permanent (or at least persistent) change to benefits thereafter. Third, as Allen and Petacchi (2018) point out, benefit cuts take time to pass; governments could swing into action to negotiate cuts as soon as GASB 67/68 passage becomes a real possibility, which makes a pre-post cutoff based on GASB 67's effective date rather arbitrary.

With an analysis at the plan-level, our objective is not to detect an "increase" in the incidence of benefit cuts post-GASB 67 as such, but to inform on the drivers of benefit cuts more broadly-what kinds of plans and governments are likely to take these actions? Allen and Petacchi 
(2018) analyze benefit cuts enacted by state governments in 2011-2012 (right at or after issuance of the Exposure Draft on GASB 67/68), and document that states with higher deficits and more indebtedness are more likely to cut benefits. We aim to (i) extend their analysis by examining benefit cuts over a longer period, including the years after passage of GASB 67/68, and also (ii) understand how different responses (benefit cuts and increased funding) interact with each other.

Table 7 presents our logistic regression analysis of benefit cuts for the 100 plans in our sample. We compile detailed, plan-level data on benefit cuts from briefs issued by the National Association of State Retirement Administrators (NASRA) in 2016 and 2018 (Brainard and Brown 2016, 2018). We code indicators for various types of benefit cuts enacted from 2012-2015 (Columns 1-7) that affect current plan members (active/terminated vested employees or retirees), outlined in Appendix C, and also combine them into a single indicator set to one for any type of benefit cut affecting these groups (Column 7). We measure independent variables at time $t-2$.

We interpret the results in relation to our baseline results for contribution increases [Eq. (1)], to compare and contrast the governments that cut benefits with those that increase funding. First, when examining the joint indicator (Column 7), government debt levels (Per Capita Shortterm Debt Issued) and government deficits (Exp_Minus_Rev) are the only factors that are significant or even approach significance, consistent with Allen and Petacchi (2018). However, on separately examining each type of benefit cut, more patterns emerge: high deficits, high indebtedness, and low rates of growth in GSP associate positively and significantly with many types of benefit cuts, consistent with the intuition that states in poorer fiscal condition are more likely to resort to cutting benefits. Correspondingly, we assess whether the increase in contributions we document in Table 3 is restricted to governments that have the ability to fund 
their plans; we find in untabulated tests that when the state's overall fiscal condition is very poor, there is no significant increase in contributions. ${ }^{28}$

Second, some measures of legal protection are consistently significant across Columns 16. While we would expect states with the weakest legal protection (i.e., Gratuity approach) to be more likely to cut benefits, we observe surprisingly that these states are actually less likely to cut benefits. Correspondingly, when we assess how legal protection interacts with contribution responses (untabulated), we find that Gratuity states also increase contributions significantly less, consistent with intuition. ${ }^{29}$ Putting these findings together: states offering the weakest protection for benefits are less likely to enact any type of change, be it cutting benefits or increasing funding; it could be the case that pension reform/funding is simply not a priority for these governments.

Teachers' plans are significantly less likely to have their benefits cut, potentially due to higher rates of unionization amongst teachers when compared to general state and local workers (Munnell et al. 2008). Benefits are also less likely to be cut in election-years, consistent with stronger political pressures in those years.

In a final test to examine whether benefit cuts and funding increases are complements or substitutes, we rerun the Eq. (1) model, for total contributions, with added controls for benefit cuts passed by the plan each year, and interactions of benefit cuts with POST-GASB67 (Table 8). The results are striking: for many types of benefit cuts, the plans that pass cuts also increase contributions more post-GASB 67. This pattern is consistent with certain governments making it

\footnotetext{
${ }^{28}$ When we partition the Eq. (1) sample into high and low subsamples based on each of the state fiscal condition variables (Exp_Minus_Rev, TTLBAL Ratio, Per Capita Short-term Debt Issued, and Per Capita Growth in GSP), we do not observe any meaningful differences in the coefficient on POST-GASB67. To increase testing power, we combine ranks of all four variables and also examine more granular subsamples (e.g., "low", "mid", and "high"). For multiple combinations of the fiscal condition variables, we observe consistently that there are no significant contribution increases for the "low" group, i.e., the states in very poor fiscal condition.

${ }^{29}$ When running Eq. (1) with added interactions for POST-GASB67*Constitution and POST-GASB67*Gratuity, we find coefficients of $0.032(\mathrm{p}$-value $=0.19)$ and $-0.020(\mathrm{p}$-value $=0.08)$ respectively, with the coefficient on POSTGASB67 remaining 0.029 (p-value $=0.02)$.
} 
a priority to tackle their pension problems: these governments negotiate benefit cuts while also increasing funding. It could also be suggestive of the political reality of pension reform: increased contributions from state governments and participating employers ultimately have to be funded by taxpayers. Especially given some perceptions that public pension benefits are overly generous, governments might only be able to "sell" increased contributions to their taxpayer base if public employees are also seen as shouldering a part of the burden, in the form of benefit cuts. ${ }^{30}$

\section{Discussion and concluding remarks}

Two GASB pronouncements-GASB Statement No. 67 Financial Reporting for Pension Plans (applicable to pension plan reporting) and GASB Statement No. 68 Accounting and Financial Reporting for Pensions (applicable to pension sponsor reporting) - both issued in June 2012, dramatically alter the pension reporting landscape for DB pension plans sponsored by state and local governments in the U.S. Collectively, they introduce provisions requiring pension liabilities to be estimated using potentially lower discount rates (hence increasing the estimated liability and any funding deficits), and requiring pension funding surpluses (deficits) to be recognized as assets (liabilities) on governmental balance sheets.

With a sample of the largest state-administered DB plans, we find that contributions into plans from employer and state sources increase significantly in the two years following initial implementation of these rules. As higher contributions reduce (both directly and indirectly) the pension liability that is required to be recognized on state governments' balance sheets, this increased funding response is consistent with governments acting to mitigate the adverse financial statement impact from GASB 67/68. Furthermore, the contribution increase is driven by governments (i) expecting a large financial statement impact from GASB 67/68, and (ii) facing

\footnotetext{
${ }^{30}$ These results also help to round out Allen and Petacchi's (2018) findings that entities opposing the Exposure Drafts are more likely to follow up with benefit cuts than higher funding (when looking at actions taken in 2011-2012).
} 
more adverse economic and political consequences from financial statement recognition of increased liabilities. These cross-sectional patterns enable us to more confidently attribute the funding shifts we observe to GASB 67/68. Therefore, we document economic consequences or "real effects" of accounting standards in the governmental sector. ${ }^{31}$

The goal of GASB $67 / 68$ stands in stark contrast to other pension regulations that were enacted in order to alter contribution behavior, of which there are two noteworthy examples in recent U.S. history. First, the Pension Protection Act of 2006 tightened minimum funding ratios for corporate plans. Second, in 2012 the U.S. Congress passed the Moving Ahead for Progress for the $21^{\text {st }}$ Century Act ("MAP-21"), which reduced mandated contributions to corporate pensions by allowing a higher discount rate for valuing pension liabilities. Predictably, corporate sponsors reduced contributions to their plans after MAP-21 (Dambra 2018). The explicit goal of both changes was to alter (either increase or decrease) contributions to pension plans. Therefore, it is not surprising that sponsors responded by altering funding practices.

In contrast, the GASB was notably agnostic about attempting to alter pension funding behavior when issuing GASB 67/68. The GASB even went so far as to state that its explicit goal was to separate pension accounting from pension funding. Nonetheless, we document systematic increases in pension contributions post-GASB 67/68, and our cross-sectional results suggest that this increase is related to those entities' motivations to soften any adverse reporting consequences. These findings point to the importance of considering managerial incentives that may lead to unintended consequences of accounting regulation.

\footnotetext{
${ }^{31}$ Our results could also be interpreted in a different light: that the recognition of pension liabilities on governments' balance sheets (as opposed to disclosure in footnotes) increased the visibility of funding deficits and increases pressures to fund. Even so, though, the trigger or impetus for increased funding comes from changes to financial statement measurement and recognition, which continues to imply that changes to accounting generated "real" effects.
} 
In sum, government entities perceive financial reporting to be important and are willing to undertake actions with cash flow consequences in order to report favorable accounting numbers. Therefore, despite the substantial differences between private and public sectors in the objectives of financial reporting and in the motivations of preparers and users, financial reporting plays an important role in shaping incentives in the public sector.

\section{References}

Advisory Commission on Intergovernmental Relations. 1987. "Fiscal discipline in the federal system: National Reform and the Experience of States. ACIR Report A-107". Washington, D.C.

Allen, Abigail, and Reining Petacchi. 2018. Public pension accounting reform: Preparer incentives and user interest. Working paper.

Andonov, Aleksander, Rob M.M.J. Bauer, and K.J. Martijn Cremers. Pension fund asset allocation and liability discount rates. Review of Financial Studies 30(8): 2555-2595.

Bens, D., Monahan, S. 2008. Altering investment decisions to manage financial reporting outcomes: Asset-backed commercial paper conduits and FIN 46. Journal of Accounting Research 46(5): 1017-1055.

BKD CPAs and Advisors. 2014. GASB's New Pension Standards. Accessed from http://www.bkd.com/articles/2014/gasbs-new-pension-standards.htm

Brainard, Keith, and Alex Brown. June 2016. Spotlight on significant reforms to state retirement systems. National Association of State Retirement Administrators (NASRA).

Brainard, Keith. 2007. Public fund survey: Summary of findings for FY 2006. National Association of State Retirement Administrators (NASRA).

Chen, W., Tan, H-T., Wang, E. 2013. Fair value accounting and managers' hedging decisions. Journal of Accounting Research 51(1): 67-103.

Chmielewski, Jack. August 2016. GASB 73: Implementation and overview. Milliman Public Employees Retirement Systems Periscope: Milliman Corporation.

Choudhary, P., Rajgopal, S., Venkatachalam, M. 2008. Accelerated vesting of stock options in anticipation of SFAS 123R. Journal of Accounting Research 47(1): 105-146.

Costello, Anna M., Reining Petacchi, and Joseph P. Weber. 2017. The impact of balanced budget restrictions on states' fiscal actions. The Accounting Review 92(1): 51-71.

Dambra, Michael J. 2018. Stakeholder conflicts and cash flow shocks: Evidence from changes in ERISA pension funding rules. The Accounting Review 93(1): 131-159. 
Feiock, Richard C., James C. Clingermayer, Christopher Stream, Barbara Coyle McCabe, and Shamima Ahmed. 2001. Political conflict, fiscal stress, and administrative turnover in American cities. State and Local Government Review 33(2): 101-108.

Fitzpatrick, Thomas J. and Amy B. Monahan. 2012. Who's afraid of good governance? State fiscal crises, public pension underfunding, and the resistance to governance reform. Working paper 1223, Federal Reserve Bank of Cleveland.

Goodhart, Eric, and Henry Reeb. May 23, 2013. GASB 67 and 68: The new world of public pension plan accounting: An actuarial perspective: Milliman Corporation.

Gore, Angela K. 2004. The effects of GAAP regulation and bond market interaction on local government disclosure. Journal of Accounting and Public Policy 23: 23-52.

Gore, Angela K., Kevin Sachs, and Charles Trczinka. 2004. Journal of Law and Economics 47: 275-306.

Governmental Accounting Standards Board (GASB). 2008. State and Local Government Use of Generally Accepted Accounting Principles For General-Purpose External Financial Reporting: Research Brief. GASB of the Financial Accounting Foundation: Norwalk, CT.

Governmental Accounting Standards Board (GASB). June 2012. Statement No: 67 of the Govermental Accounting Standards Board: Financial Reporting for Pension Plans, an amendment of GASB Statement No: 25. GASB of the Financial Accounting Foundation: Norwalk, CT.

Governmental Accounting Standards Board (GASB). June 2012. Statement No: 68 of the Govermental Accounting Standards Board: Accounting and Financial Reporting for Pensions, an amendment of GASB Statement No: 27. GASB of the Financial Accounting Foundation: Norwalk, CT.

Graham, John., Michelle Hanlon, Terry Shevlin. 2011. Real effects of accounting rules: Evidence from multinational firms' investment locations and profit repatriation decisions. Journal of Accounting Research 49(1): 137-185.

Graham, John, Campbell Harvey, Shivaram Rajgopal. 2005. The economic implications of corporate financial reporting. Journal of Accounting and Economics 40: 3-73.

Hallman, Nicholas, and Inder K. Khurana. 2015. State pension liabilities and credit assessments. Accounting Horizons 29(4): 943-967.

Horwitz, Bertrand, Kolodny, Richard. 1980. The economic effects of involuntary uniformity in the financial reporting of research and development expenditures. Journal of Accounting Research 18: 38-74.

Imhoff, Eugene, Thomas, Jacob. 1988. Economic consequences of accounting standards: The lease disclosure rule change. Journal of Accounting and Economics 10(4): 277-310.

Khumawala, Saleha, Tharinda Ranasinghe, and Claire Yan. 2017. Real effects of governmental accounting standards: Evidence from GASB Statement No: 53: Accounting and Financial Reporting for Derivative Instruments. Working paper. 
Kido, Nolan, Reining Petacchi, and Joseph P. Weber. 2012. Journal of Accounting research 50(2): 443-475.

Kilroy, Meaghan. March 24, 2015. S\&P: Public pension funds dictating state budgets, policy and credit ratings. Pensions \& Investments: Crain Communications, Inc.

Marks, Barry R., and K. K. Raman. 1988. The effect of unfunded accumulated and projected pension obligations on governmental borrowing costs. Contemporary Accounting Research 4(2): 595-608.

Martell, Christine R., Sharon N. Kioko, and Tima Moldogaziev. 2013. Impact of unfunded pension obligations on credit quality of state governments. Public Budgeting \& Finance: 24-54.

McCabe, B., R.C. Feiock, J. Clinger and C. Stream. 2008. Turnover among city managers: The role of political and economic change. Public Administration Review 68(2): 380-387.

McGregor, Jena. 2017. The Washington Post. The problem with Donald Trump's blame game. February 21, 2017.

Moodys' Investor Service. June 2014. Moodys' US public pension analysis largely unchanged by new GASB 67/68 Standards. Moodys’ U.S. Public Finance Report number: 171874.

Moodys' Investor Service. 16 March 2015. US Public Pensions: New Pension Accounting increases clarity of plan funding trajectories. Moodys' Corporation, Inc.

Moodys' Investor Service. July 2017. Rating Symbols and Definitions. Moodys' Corporation, Inc.

Mortimer, John W., and Linda R. Henderson. 2014. Measuring pension liabilities under GASB Statement No: 68. Accounting Horizons 28(3): 421-454.

Munnell, Alicia H., and Jean-Pierre Aubry. 2016. The funding of state and local pensions: 20152020. Center for State and Local Government Excellence Issue Brief: Washington, D.C. Accessed from www.slge.com

Munnell, Alicia H., Jean-Pierre Aubry, Josh Hurwitz, and Laura Quinby. 2012. How would GASB proposals affect state and local pension reporting? State and Local Plans Issue in Brief 17. Chestnut Hill, MA: Center for Retirement Research at Boston College.

Munnell, Alicia H., Alex Golub-Sass, Kelly Haverstick, Mauricio Soto, and Gregory Wiles. 2008. Why have some states introduced defined contribution plans? State and Local Plans Issue in Brief 3. Chestnut Hill, MA: Center for Retirement Research at Boston College.

Munnell, Alicia H., Kelly Haverstick, Jean-Pierre Aubry. 2008. Why does funding status vary among state and local plans? State and Local Plans Issue in Brief 6. Chestnut Hill, MA: Center for Retirement Research at Boston College.

Munnell, Alicia H., Kelly Haverstick, Jean-Pierre Aubry, and Alex Golub-Sass. 2008. Why don't some states and localities pay their required pension contributions? State and Local Plans Issue in Brief 7. Chestnut Hill, MA: Center for Retirement Research at Boston College. 
Munnell, Alicia H., Kelly Haverstick, Mauricio Soto, and Jean-Pierre Aubry. 2008. What do we know about the universe of state and local plans? State and Local Plans Issue in Brief 4. Chestnut Hill, MA: Center for Retirement Research at Boston College..

Munnell, Alicia H. and Laura Quinby. 2012. "Legal Constraints on Changes in State and Local Pensions." State and Local Plans Issue in Brief 25. Chestnut Hill, MA: Center for Retirement Research at Boston College.

Munnell, Alicia H., and Mauricio Soto. 2007. State and local pensions are different from private plans. State and Local Plans Issue in Brief 1. Chestnut Hill, MA: Center for Retirement Research at Boston College.

Naughton, James, Reining Petacchi, and Joseph Weber. 2015. Public pension accounting rules and economic outcomes. Journal of Accounting and Economics 59: 221-241.

Rauh, Joshua D. 2017. Hidden debt, hidden deficits: 2017 Edition - How pension promises are consuming state and local budgets. Hoover Institution Essay.

Rauh, Joshua D., and Robert Novy-Marx. 2011. Public pension promises: How big are they and what are they worth? Journal of Finance 66(4): 1207-1245.

Rauh, Joshua D., and Robert Novy-Marx. 2012. Fiscal imbalances and borrowing costs: Evidence from state investment losses. American Economic Journal: Economic Policy 4(2): 182-213.

Rich, Kevin T., and Jean X. Zhang. 2014. Municipal accounting restatements and financial manager turnover. Working paper.

Rich, Kevin T., and Jean X. Zhang. 2015. Unfunded public pension liabilities and local citizen oversight. Accounting Horizons 29(1): 23-39.

S\&P Global Market Intelligence. January 5, 2017. U.S. State Sector 2017 Outlook: Protracted slow economic growth casts a shadow. Standard \& Poor's Global Market Intelligence, a division of Standard \& Poor's Global Inc.

S\&P Global Ratings. September 2016. RatingsDirect: U.S. State Pensions: Weak market returns will contribute to rise in expense: Standard \& Poor's Global Market Intelligence, a division of Standard \& Poor's Global Inc.

S\&P Ratings Services. July 2013. RatingsDirect: Credit FAQ: Standard \& Poor's Approach to Pension Liabilities in Light of GAB 67 and 68. Standard \& Poor's Financial Services LLC.

Senta, Jennifer Sorensen. January 2014. GASB 67/68: Beginning implementation and overview. Milliman Public Employees Retirement Systems Periscope: Milliman Corporation.

U.S. Department of Labor Bureau of Labor Statistics. 2007. National Compensation Survey: Employee Benefits in Private Industry in the United States, 2005. Bulletin 2589. Washington, D.C.: U.S. Government Printing Office. 
Vermeer, Thomas E., Alan K. Styles, and Terry K. Patton. 2012. Do local governments present required disclosures for defined benefit pension plans? Journal of Accounting and Public Policy 31: 44-68.

Winningham, William. 2014. GASB 67/68: Depletion date projections. Milliman Public Employees Retirement Systems Periscope: Milliman Corporation. 


\section{Appendix A - Estimation of the discount rate under GASB 67/68}

Step 1: Project future benefit payments based on the benefit terms as of the fiscal year end.

○ Benefits should be projected for all current plan members, whether active/inactive, currently receiving benefits/not

- Projected benefits should include all automatic/substantively automatic COLAs, future increases in salary, and future service

- Projection to be done on "closed group" rather than "open group" basis, i.e., benefits expected to be paid to future employees should be excluded from the benefit projections

\section{Step 2: Project plan assets}

- Assets are to be projected by taking into account expected inflows (contributions) and outflows (benefit payments, expenses) associated with current members

- Unlike benefit payment projections, expected contributions for future members can be included to the extent to which these contributions exceed the expected service cost associated with these new members

- Contributions can come from employers, employees, or non-employer funding source

- If the plan's contribution rate is set by statute, or there is a formal written funding policy in place (such that it is reasonable to assume that the contribution will continue to be made), then professional judgment can be used in projecting the most recent five years of contribution history into the future

- If no statutory contribution basis / formal written policy exists, then the average contribution over the most recent five-year period is the maximum projected future contribution

\section{Step 3: Determine the single equivalent discount rate}

- If Step 1 and Step 2 demonstrate that assets are projected to be sufficient to cover benefit payments for all periods, then the long-term ERR on plan assets may be used to discount all benefit payments

- If Step 1 and Step 2 indicate that there is a date at which plan assets are depleted (i.e., a "projected depletion date" exists), the plan actuary must then calculate a blended discount rate, by (i) discounting all benefit payments expected to be paid up until the projected depletion date using the ERR on plan assets, and (ii) discounting all benefits payments after that date using a municipal bond rate.

- Solve for the single equivalent discount rate that, when applied to all the cash flows, produces the same total present value as the dual discount rate streams described above; this single equivalent discount rate (also known as the "blended rate") is used to calculate the total liability per GASB $67 / 68$.

\section{Alternative evaluations of sufficiency}

- Instead of the above approach, which can be complex, both GASB 67 (paragraph 43) and GASB 68 (paragraph 29) allow for alternative evaluations of projected solvency if they can be reliably made.

- The standards prescribe no particular alternative method; it is left to professional judgment and so the determination of whether an alternative approach is warranted is up to actuary and auditor.

- For example: "From a practical standpoint, a good candidate for an alternative approach would be a plan that is relatively well-funded, where contributions are based on a 
conservative, actuarially-based funding policy. E.g., the plan actuary may be able to demonstrate to the auditor's satisfaction that a plan that is $80 \%$ funded, with a solid track record of adhering to a funding policy based on contributing the normal cost +20 -year closed amortization of unfunded liabilities, is mathematically certain to remain solvent if certain assumptions are met" (Winningham 2014). 
Appendix B - Measurement and Recognition changes required by GASB 67 and GASB 68

\begin{tabular}{|c|c|c|c|}
\hline & $\begin{array}{l}\text { GASB Statements No: } 25 \text { and } \\
27\end{array}$ & GASB Statements No: 67 and 68 & Expected impact \\
\hline \multirow[t]{2}{*}{$\begin{array}{l}\text { Measurement of the Total } \\
\text { Pension Liability (TPL) }\end{array}$} & $\begin{array}{l}\text { 1. Discount rate: Projected } \\
\text { future benefit payments } \\
\text { discounted at the long-term } \\
\text { ERR on pension plan assets }\end{array}$ & $\begin{array}{l}\text { 1. Discount rate: If plan assets are } \\
\text { projected to be insufficient to cover } \\
\text { projected benefit payments for all } \\
\text { periods, then a "projected depletion date" } \\
\text { or "crossover point" exists. } \\
\text { (i) all benefit payments expected to be } \\
\text { paid up until the projected depletion date } \\
\text { are to be discounted using the ERR on } \\
\text { plan assets, and } \\
\text { (ii) all benefits payments after that date } \\
\text { are to be discounted using a high-quality } \\
\text { municipal bond index rate } \\
\text { The single equivalent discount rate that } \\
\text { produces the same total present value as } \\
\text { the two discounted streams from (i) and } \\
\text { (ii) is the plan's overall, "blended" } \\
\text { discount rate. }\end{array}$ & $\begin{array}{l}\text { Typically, ERRs are } \\
\text { higher than } \\
\text { municipal bond } \\
\text { index rates as public } \\
\text { pensions invest } \\
\text { extensively in } \\
\text { equities and } \\
\text { alternative assets. } \\
\text { Therefore, } \\
\text { "blended" discount } \\
\text { rates are expected to } \\
\text { be lower than the } \\
\text { ERR, leading to } \\
\text { higher estimates of } \\
\text { the TPL. }\end{array}$ \\
\hline & $\begin{array}{l}\text { 2. Substantively automatic } \\
\text { benefit changes are not } \\
\text { required to be included in } \\
\text { benefit projections. }\end{array}$ & $\begin{array}{l}\text { 2. When projecting future benefit } \\
\text { payments, any "substantively automatic" } \\
\text { changes in future benefit payments are } \\
\text { also to be included. Substantively } \\
\text { automatic" benefit changes are defined as } \\
\text { those "ad hoc" changes that the employer } \\
\text { determines based on its past practice and } \\
\text { future expectations of granting the } \\
\text { change that the item will be granted in } \\
\text { the future. A common example is ad-hoc } \\
\text { cost-of-living adjustments (COLAs). } \\
\text { Some factors to be considered in } \\
\text { determining whether an ad-hoc COLA }\end{array}$ & $\begin{array}{l}\text { The inclusion of ad- } \\
\text { hoc COLAs that are } \\
\text { deemed } \\
\text { substantively } \\
\text { automatic will lead } \\
\text { to higher estimates } \\
\text { of the TPL. }\end{array}$ \\
\hline
\end{tabular}




\begin{tabular}{|c|c|c|c|}
\hline & & $\begin{array}{l}\text { should be deemed "substantively } \\
\text { automatic": } \\
\text { (i) The plan's historical pattern of } \\
\text { granting (or denying) ad-hoc COLAs } \\
\text { (ii) Consistency in the amount of the } \\
\text { COLAs, or the amounts relative to a pre- } \\
\text { determined inflation index } \\
\text { (iii) Whether there is evidence indicating } \\
\text { that the ad-hoc COLAs will not be } \\
\text { granted in future years }\end{array}$ & \\
\hline & $\begin{array}{l}\text { 3. Any one of six actuarial cost } \\
\text { methods are permitted, of } \\
\text { which the most common } \\
\text { method is Entry Age Normal } \\
\text { (EAN), followed by the } \\
\text { Projected Unit Credit (PUC) } \\
\text { method. }\end{array}$ & 3. Only the EAN method is permitted. & $\begin{array}{l}\text { Up until the point of } \\
\text { retirement, the EAN } \\
\text { method recognizes a } \\
\text { larger accumulated } \\
\text { pension obligation } \\
\text { for active employees } \\
\text { than the PUC } \\
\text { method. }\end{array}$ \\
\hline $\begin{array}{l}\text { Measurement of plan assets, } \\
\text { i.e., "Fiduciary Net Position" } \\
\text { (FNP) }\end{array}$ & $\begin{array}{l}\text { Plan assets may be measured } \\
\text { with a market-related value, } \\
\text { where changes in market value } \\
\text { may be smoothed over a three- } \\
\text { to-five year period. }\end{array}$ & $\begin{array}{l}\text { Plan assets must be measured at fair } \\
\text { value as of the measurement date. }\end{array}$ & \\
\hline Balance sheet recognition & $\begin{array}{l}\text { Only the Net Pension } \\
\text { Obligation (NPO) is } \\
\text { recognized as a liability, where } \\
\text { the NPO = cumulative excess } \\
\text { of required contributions over } \\
\text { actual contributions }\end{array}$ & $\begin{array}{l}\text { The Net Pension Liability (NPL) must be } \\
\text { recognized as a liability, where the NPL } \\
\text { = excess of the Total Pension Liability } \\
\text { (TPL) over the Fiduciary Net Position } \\
\text { (FNP) }\end{array}$ & \\
\hline Additional liabilities & Not applicable & $\begin{array}{l}\text { Deferred inflows and outflows: } \\
\text { (i) Liability gains/losses } \\
\text { (ii) Assumption changes } \\
\text { (iii) Asset gains/losses }\end{array}$ & \\
\hline
\end{tabular}




\begin{tabular}{|c|c|c|}
\hline Income statement recognition & $\begin{array}{l}\text { Generally, pension expense is } \\
\text { equal to the Annual Required } \\
\text { Contribution (ARC). The ARC } \\
\text { = normal cost + payment to } \\
\text { amortize the unfunded } \\
\text { actuarial accrued liability in } 30 \\
\text { years. The exact computation } \\
\text { of pension expense depends on } \\
\text { whether a Net Pension } \\
\text { Obligation (NPO) was } \\
\text { recorded. The NPO, which was } \\
\text { the balance sheet liability } \\
\text { under GASB } 25 / 27 \text {, was } \\
\text { calculated as the cumulative } \\
\text { difference between the annual } \\
\text { pension cost and the } \\
\text { employer's contribution to the } \\
\text { plan. If there is no NPO, then } \\
\text { pension expense is equal to the } \\
\text { ARC (i.e., normal cost). If } \\
\text { there is an NPO, then pension } \\
\text { expense = ARC + one year of } \\
\text { interest on NPO + adjustment } \\
\text { to NPO to remove amounts in } \\
\text { ARC already in the NPO. }\end{array}$ & $\begin{array}{l}\text { Pension expense = normal cost } \\
\text { + interest on NPL } \\
\text { - Expected return on plan assets } \\
\text { +/- Liability gain/loss (amortized) } \\
\text { +/- Asset gain/loss (amortized over } 5 \\
\text { yrs) } \\
\text { +/- Plan changes (immediate } \\
\text { recognition) } \\
\text { +/- Assumption changes (amortized) }\end{array}$ \\
\hline Funding policy & $\begin{array}{l}\text { Many governments' funding } \\
\text { policies were defined based on } \\
\text { the ARC, as defined by GASB } \\
25 / 27 \text {. }\end{array}$ & $\begin{array}{l}\text { No reference to funding policies; GASB } \\
67 / 68 \text { represent an explicit effort by the } \\
\text { GASB to delink accounting and funding } \\
\text { for governmental plans. }\end{array}$ \\
\hline
\end{tabular}




\section{Appendix C: Coding of the benefit cuts measures}

We rely on issue briefs created by the National Association of State Retirement Administrators (NASRA) to create measures of pension benefit cuts (or "reforms", as the Issue Briefs refer to them). The Issue Briefs are available at: https://www.nasra.org/issuebriefs. We primarily use the Briefs titled "Significant Reforms to State Retirement Systems", issued in June 2016 and December 2018. We supplement these with Briefs titled "State Hybrid Retirement Plans", "Cost-of-Living Adjustments", and "Employee Contributions to Public Pension Plans".

We compile data on the following different types of benefit reforms applicable to current plan members (i.e., currently active employees, terminated vested employees, or retirees):

(1) Has the annual retirement benefit been capped? e.g., to a certain percentage of final average salary, such as $80 \%$. If so, then "Annual Benefit Capped" is set to one, and else to zero.

(2) Has the annual benefit multiplier been reduced? i.e., the rate at which employees accrue benefits for every additional year of service, which is typically around $2 \%$ per annum. If so, then "Benefit Multiplier Reduced" is set to one, and else to zero.

(3) Has the calculation of "final average salary" been changed such that the final average salary is likely to be lower? We observe this done in two ways: one, the period over which final average salary is determined is increased, most commonly from 3 to 5 years; two, a more restrictive definition of "salary" is introduced, which disallows e.g., overtime pay or bonuses or unusually large year-on-year increases during the determination period from being included, or explicitly caps pensionable compensation to a certain dollar amount. The latter change, i.e., restricting what can be included in "salary" during the determination period, is often introduced to mitigate concerns of pension "spiking". If yes, then "Final Salary Reduced" is set to one, and else to zero.

(4) Have the age-service requirements for retirement been made more onerous? This is usually done by increasing the minimum age or service requirements for normal or early retirement; or by eliminating the option to take normal (unreduced) retirement at any age with a certain number of years of service; or by increasing the rate at which benefits are reduced for taking early retirement. If yes, then "Retirement Age Increased" is set to one, and else to zero.

(5) Have Cost-of-Living Adjustments (COLA) been reduced? We observe this done in many ways: reducing the guaranteed COLA rate, or delaying COLA onset for retirees, or most commonly by making the COLAs a function of inflation and the plan's asset returns and funding status "risk-based" COLAs. If yes, then "COLA Reduced" is set to one, and else to zero.

(6) Have mandated employee contribution rates been increased? This is done either by increasing the mandated rate, which ranges from 5\%-10\% of covered payroll, or by instituting a "sharedrisk" system, where employee contribution rates are a function of the plan's asset returns and funded status. If yes, then "Employee Contributions Increased" is set to one, and else to zero.

(7) Have other changes been made that reduce the expected pension benefit? e.g., the benefit vesting period is increased, the interest rate applicable to purchase of service credits is increased, or the interest rate paid to refunded member contributions is reduced. If yes, then "Other Benefit Reductions" is set to one, and else to zero.

(8) If any of the above benefit cuts have been passed, then a joint indicator "Any Benefit Reductions" is set to one, and else to zero. 
Table 1

Variable Measurement

Variable

\begin{tabular}{|c|c|}
\hline Employer Contribution / Payroll & $\begin{array}{l}\text { The dollar amount of contributions paid into the plan by the employer, divided } \\
\text { by prior-year covered payroll }\end{array}$ \\
\hline Employer + State Contribution / Payroll & $\begin{array}{l}\text { The sum of (i) dollar amount of contributions paid into the plan by the employer } \\
\text { and (ii) the dollar amount of contributions paid into the plan by the sponsoring } \\
\text { state, divided by prior-year covered payroll }\end{array}$ \\
\hline Employee Contribution / Payroll & $\begin{array}{l}\text { The dollar amount of contributions paid into the plan by the employees, divided } \\
\text { by prior-year covered payroll }\end{array}$ \\
\hline Total Contribution / Payroll & $\begin{array}{l}\text { The dollar amount of total contributions paid into the plan (i.e., by the employer, } \\
\text { state, and employees), divided by prior-year covered payroll }\end{array}$ \\
\hline Covered Payroll & $\begin{array}{l}\text { The dollar value of the total pensionable earnings of the pension plan } \\
\text { participants }\end{array}$ \\
\hline Pension Assets & The actuarial value of pension plan assets \\
\hline Pension Liabilities & The actuarial accrued pension liability obligation \\
\hline Funding Ratio & $\begin{array}{l}\text { The ratio of Pension Assets divided by Pension Liabilities, both measured in the } \\
\text { same fiscal year }\end{array}$ \\
\hline Required Contributions & $\begin{array}{l}\text { The dollar amount of the employer's annual required contribution as reported in } \\
\text { the required supplementary tables for GASB accounting purposes, set equal to } \\
\text { the Annual Required Contribution (ARC) prior to GASB } 67 / 68 \text { and set equal to } \\
\text { the Actuarially Determined Contribution (ADC) after GASB } 67 / 68\end{array}$ \\
\hline \% Required Contributions Paid & $\begin{array}{l}\text { The percent of the required contribution actually contributed into the plan by the } \\
\text { plan sponsor. The degree to which the plan sponsor regularly and fully pays its } \\
\text { required contributions to the plan - is a critical factor in assessing the current } \\
\text { and future health of a pension plan and an indicator as to whether or not the } \\
\text { costs of funding the pension plan creates fiscal stress for the pension plan } \\
\text { sponsor. In the multivariate regressions, we compute a five-year average of the } \\
\% \text { Required Contributions Paid for the three-year period ending in the year prior } \\
\text { to the current year. }\end{array}$ \\
\hline Plan Covers Teachers & $\begin{array}{l}\text { A dummy variable set equal to one if the plan covers teachers, and zero } \\
\text { otherwise }\end{array}$ \\
\hline Accrued Liability / Tax Revenue & The accrued pension liability scaled by tax revenues \\
\hline Unfunded Accrued Liability / Tax Revenue & $\begin{array}{l}\text { The unfunded accrued pension liability (i.e., the portion of the liabilities that } \\
\text { exceeds pension assets), scaled by tax revenues }\end{array}$ \\
\hline Exp_Minus_Rev (\$ per capita) & $\begin{array}{l}\text { The per capita difference between final expenditures and final revenues in the } \\
\text { general fund and then add back any midyear spending cuts or tax changes }\end{array}$ \\
\hline TTLBAL Ratio & $\begin{array}{l}\text { The ratio of total balance to expenditures in the general fund, where total } \\
\text { balances are the sum of the general fund balances and the state's budget } \\
\text { stabilization fund balances (i.e., rainy day fund balances) }\end{array}$ \\
\hline
\end{tabular}




\section{Table 1 (Continued) Variable Measurement}

\begin{tabular}{|c|c|}
\hline Variable & Definition \\
\hline Per Capita Short-Term Debt Issued & The amount of short-term debt issued during the year, per capita \\
\hline Per Capita Growth in Gross State Product & The percentage change in real gross state product, per capita \\
\hline Balanced Budget & $\begin{array}{l}\text { The value from an index produced by the Advisory Commission on } \\
\text { Intergovernmental Relations (ACIR 1987), where the variable ranges from } 0 \text { to } \\
\text { 10, with higher values indicating more rigorous balanced budget provisions }\end{array}$ \\
\hline Union Membership & $\begin{array}{l}\text { The percentage of public sector employees who are members of a labor union or } \\
\text { of an employee association similar to a union }\end{array}$ \\
\hline Election & $\begin{array}{l}\text { An indicator variable set equal to one if the state has a gubernatorial election in } \\
\text { the current year, and zero otherwise }\end{array}$ \\
\hline Corruption & $\begin{array}{l}\text { A dummy variable set equal to one for above-median federal convictions per } \\
\text { capita of local, state, and federal officials for public corruption in that year }\end{array}$ \\
\hline Constitution & $\begin{array}{l}\text { A dummy variable set equal to one if the state constitution provides legal } \\
\text { constraints on changing benefits for current workers, such that the state } \\
\text { constitution prohibits a state from passing any laws that impair pension benefits. } \\
\text { Constitutional protections are considered the strongest type of legal protections } \\
\text { for pension plans. }\end{array}$ \\
\hline Gratuity & $\begin{array}{l}\text { A dummy variable set equal to one if the legal constraints on changing benefits } \\
\text { for current workers are minimal, such that the state can withdraw or change } \\
\text { benefits at any time. In such situations, the pension benefits are viewed as a } \\
\text { "gratuity" that the state could change at any time. Gratuity protections are } \\
\text { considered the weakest type of legal protections for pension plans. }\end{array}$ \\
\hline Expected Rate of Return (ERR) & $\begin{array}{l}\text { The managerial assumption on the rate of return based on the expected riskiness } \\
\text { of the pension plan assets, expressed as a percentage }\end{array}$ \\
\hline Blended Discount Rate & $\begin{array}{l}\text { The single discount rate that produces an equivalent present value of pension } \\
\text { liabilities as the combination of using (i) the ERR as the discount rate to } \\
\text { compute the present value of pension liabilities for which there are enough } \\
\text { pension assets projected to cover projected benefit payments (i.e., up to the } \\
\text { "projected depletion date" or the "crossover point") and (ii) a high-quality tax- } \\
\text { exempt municipal bond rate as the discount rate to compute the present value of } \\
\text { liabilities for the remainder of the projected benefit payments }\end{array}$ \\
\hline
\end{tabular}


Table 2

Descriptive Statistics

Panel A: Pre-Period (Years t-2 and t-1)

\begin{tabular}{|c|c|c|c|c|c|c|c|}
\hline & $\mathbf{P 5}$ & $\mathbf{P 2 5}$ & P50 & P75 & $\mathbf{P 9 5}$ & Mean & Std \\
\hline Pension Assets (\$millions) & 1,531 & 5,144 & 11,745 & 24,273 & 85,276 & 22,388 & 31,249 \\
\hline Pension Liabilities (\$millions) & 2,151 & 6,859 & 17,020 & 34,357 & 106,302 & 30,949 & 41,393 \\
\hline Funding Ratio $(\%)$ & $46.3 \%$ & $61.9 \%$ & $72.2 \%$ & $84.0 \%$ & $99.9 \%$ & $73.4 \%$ & $16.1 \%$ \\
\hline$\%$ Required Contributions Paid $(\%)$ & $47 \%$ & $78 \%$ & $93 \%$ & $100 \%$ & $107 \%$ & $88 \%$ & $19 \%$ \\
\hline Plan Covers Teachers & 0 & 0 & 0 & 1 & 1 & 0.46 & 0.50 \\
\hline Accrued Liability / Tax Revenue (\%) & $23 \%$ & $60 \%$ & $125 \%$ & $282 \%$ & $472 \%$ & $179 \%$ & $146 \%$ \\
\hline Unfunded Accrued Liability / Tax Revenue (\%) & $0 \%$ & $10 \%$ & $36 \%$ & $73 \%$ & $147 \%$ & $51 \%$ & $48 \%$ \\
\hline Exp_Minus_Rev (\$ per capita) & -158 & -73 & -9 & 63 & 155 & -12 & 105 \\
\hline TTLBAL Ratio (\%) & $-0.60 \%$ & $2.50 \%$ & $6.35 \%$ & $11.80 \%$ & $35.30 \%$ & $12.51 \%$ & $29.67 \%$ \\
\hline Per Capita Short-Term Debt Issued ( $\$$ per capita) & -34 & -0.25 & 0.00 & 1.68 & 29 & 1.27 & 80.84 \\
\hline Per Capita Growth in Gross State Product (\%) & $-2.60 \%$ & $-0.40 \%$ & $0.80 \%$ & $1.60 \%$ & $4.00 \%$ & $0.65 \%$ & $1.72 \%$ \\
\hline Balanced Budget (Index ranging from 0 to 10 ) & 3 & 6 & 9 & 10 & 10 & 7.90 & 2.62 \\
\hline Union Membership & 0 & 0 & 0 & 0 & 0 & 0.11 & 0.05 \\
\hline Election & 0 & 0 & 0 & 0 & 1 & 0.14 & 0.35 \\
\hline Corruption & 0 & 0 & 1 & 1 & 1 & 0.50 & 0.50 \\
\hline Constitution & 0 & 0 & 0 & 0 & 1 & 0.16 & 0.37 \\
\hline Gratuity & 0 & 0 & 0 & 0 & 1 & 0.10 & 0.30 \\
\hline Covered Payroll (\$millions) & 342 & 1,437 & 3,255 & 6,148 & 15,269 & 5,187 & 6,704 \\
\hline Employee Contributions / Payroll & 0.00 & 0.04 & 0.07 & 0.09 & 0.11 & 0.06 & 0.03 \\
\hline Employer Contributions / Payroll & 0.05 & 0.08 & 0.12 & 0.16 & 0.33 & 0.14 & 0.09 \\
\hline Employer + State Contributions / Payroll & 0.05 & 0.09 & 0.12 & 0.17 & 0.33 & 0.15 & 0.09 \\
\hline Total Contributions / Payroll & 0.10 & 0.15 & 0.20 & 0.26 & 0.41 & 0.22 & 0.10 \\
\hline
\end{tabular}

Notes: All variables are defined in Table 1.

P5, P25, P50, P75, and P95 denote the 5th, 25th, 50th, 75th, and 95th percentiles of the distribution respectively. Std denotes Standard Deviation. 
Table 2 (Continued)

Descriptive Statistics

Panel B: Post-Period (Years t0 and $\mathrm{t}+1$ )

\begin{tabular}{|c|c|c|c|c|c|c|c|}
\hline & P5 & $\mathbf{P 2 5}$ & P50 & P75 & P95 & Mean & Std \\
\hline Pension Assets (\$millions) & 1,711 & 6,019 & 13,483 & 26,386 & 91,502 & 24,338 & 32,903 \\
\hline Pension Liabilities (\$millions) & 2,438 & 8,151 & 18,217 & 37,677 & 105,402 & 33,247 & 43,218 \\
\hline Funding Ratio (\%) & $48.1 \%$ & $61.4 \%$ & $72.8 \%$ & $83.0 \%$ & $99.8 \%$ & $72.9 \%$ & $15.4 \%$ \\
\hline$\%$ Required Contributions Paid (\%) & $50 \%$ & $80 \%$ & $96 \%$ & $100 \%$ & $108 \%$ & $89 \%$ & $19 \%$ \\
\hline Accrued Liability / Tax Revenue (\%) & $24 \%$ & $60 \%$ & $131 \%$ & $295 \%$ & $489 \%$ & $190 \%$ & $156 \%$ \\
\hline Unfunded Accrued Liability / Tax Revenue (\%) & $1 \%$ & $9 \%$ & $37 \%$ & $74 \%$ & $148 \%$ & $50 \%$ & $49 \%$ \\
\hline Exp_Minus_Rev (\$ per capita) & -246 & -69 & -16 & 27 & 123 & -20 & 124 \\
\hline TTLBAL Ratio (\%) & $0.50 \%$ & $3.60 \%$ & $7.70 \%$ & $13.60 \%$ & $33.40 \%$ & $14.23 \%$ & $28.13 \%$ \\
\hline Per Capita Growth in Gross State Product (\%) & $-0.10 \%$ & $0.90 \%$ & $1.50 \%$ & $2.10 \%$ & $3.30 \%$ & $1.48 \%$ & $1.33 \%$ \\
\hline Balanced Budget (Index ranging from 0 to 10 ) & 3 & 6 & 9 & 10 & 10 & 7.96 & 2.54 \\
\hline Union Membership & 0 & 0 & 0 & 0 & 0 & 0.11 & 0.05 \\
\hline Election & 0 & 0 & 0 & 1 & 1 & 0.38 & 0.49 \\
\hline Corruption & 0 & 0 & 1 & 1 & 1 & 0.54 & 0.50 \\
\hline Constitution & 0 & 0 & 0 & 0 & 1 & 0.16 & 0.37 \\
\hline Gratuity & 0 & 0 & 0 & 0 & 1 & 0.10 & 0.31 \\
\hline Blended Discount Rate (\%) & $5.79 \%$ & $7.50 \%$ & $7.50 \%$ & $7.95 \%$ & $8.00 \%$ & $7.49 \%$ & $0.65 \%$ \\
\hline Covered Payroll (\$millions) & 337 & 1,443 & 3,416 & 6,310 & 15,671 & 5,291 & 6,840 \\
\hline Employer + State Contributions / Payroll & 0.05 & 0.10 & 0.14 & 0.19 & 0.40 & 0.17 & 0.11 \\
\hline Total Contributions / Payroll & 0.11 & 0.17 & 0.23 & 0.29 & 0.49 & 0.25 & 0.12 \\
\hline
\end{tabular}

Notes: All variables are defined in Table 1

P5, P25, P50, P75, and P95 denote the 5th, 25th, 50th, 75th, and 95th percentiles of the distribution respectively. Std denotes Standard Deviation.

$*, * *$, and $* * *$ indicate significant differences in means when compared to pre-period values at $\mathrm{p}<0.10, \mathrm{p}<0.05$, and $\mathrm{p}<0.01$, respectively 
Table 3

Regressions of Contributions around GASB 67

\begin{tabular}{|c|c|c|c|c|c|c|c|}
\hline & \multirow[t]{2}{*}{$\begin{array}{l}\text { Predicted } \\
\text { Sign } \\
\end{array}$} & \multicolumn{2}{|c|}{$\begin{array}{c}\text { Panel A: } \\
\text { Employee Contributions }\end{array}$} & \multicolumn{2}{|c|}{$\begin{array}{c}\text { Panel B: } \\
\text { Employer Contributions }\end{array}$} & \multicolumn{2}{|c|}{$\begin{array}{c}\text { Panel C: } \\
\text { Total Contributions }\end{array}$} \\
\hline & & Estimate & P-Value & Estimate & P-Value & Estimate & P-Value \\
\hline Intercept & & 0.069 & $0.020 * *$ & 0.444 & $<.0001 * * *$ & 0.511 & $<.0001 * * *$ \\
\hline POST-GASB 67 & + & 0.004 & 0.277 & 0.028 & $0.042 * *$ & 0.030 & $0.008 * * *$ \\
\hline Funding Ratio (Prior-Year) & $+/-$ & -0.009 & 0.738 & -0.367 & $0.0002 * * *$ & -0.457 & $<.0001 * * *$ \\
\hline$\%$ Required Contributions Paid & + & 0.00003 & 0.998 & 0.096 & $0.024 * *$ & 0.135 & $0.003 * * *$ \\
\hline Plan Covers Teachers & + & 0.004 & 0.648 & -0.045 & $0.001 * * *$ & -0.019 & 0.110 \\
\hline Accrued Liability / Tax Revenue & $+/-$ & -0.003 & 0.369 & 0.008 & 0.201 & 0.002 & 0.722 \\
\hline Unfunded Accrued Liability / Tax Revenue & $+/-$ & 0.014 & 0.135 & -0.065 & $0.026 * *$ & -0.049 & $0.078 *$ \\
\hline Exp_Minus_Rev & - & 0.000003 & 0.811 & 0.000003 & 0.958 & -0.000008 & 0.906 \\
\hline TTLBAL Ratio & $+/-$ & 0.005 & 0.337 & -0.047 & $0.027 * *$ & 0.039 & 0.122 \\
\hline Per Capita Short-Term Debt Issued & - & 0.000007 & 0.483 & 0.000004 & 0.890 & -0.00003 & 0.408 \\
\hline Per Capita Growth in Gross State Product & + & 0.141 & 0.222 & 0.004 & 0.988 & 0.491 & 0.154 \\
\hline Balanced Budget & - & 0.0006 & 0.700 & -0.0054 & 0.241 & -0.0067 & $0.083 *$ \\
\hline Union Membership & + & -0.059 & 0.442 & -0.093 & 0.605 & 0.091 & 0.620 \\
\hline Election & + & 0.0006 & 0.808 & 0.0081 & 0.196 & 0.0064 & 0.295 \\
\hline Corruption & - & 0.002 & 0.723 & -0.020 & 0.161 & -0.003 & 0.772 \\
\hline Constitution & + & 0.011 & 0.264 & 0.011 & 0.765 & 0.045 & 0.105 \\
\hline Gratuity & - & -0.002 & 0.816 & -0.063 & $0.0003 * * *$ & -0.055 & $0.004 * * *$ \\
\hline $\mathrm{N}$ & & 400 & & 400 & & 400 & \\
\hline $\mathrm{R}^{2}$ & & $9.9 \%$ & & $39.4 \%$ & & $55.4 \%$ & \\
\hline
\end{tabular}

Notes:

All variables are defined in Table 1.

All dependent variables are scaled by prior-year covered payroll.

Standard errors are clustered at the state level.

All model specifications include indicator variables for each quarter + year combination (e.g., Q1 2012, Q2 2012, Q3 2012, Q4 2012, Q1 2013, Q2 2013, etc.)

All reported p-values are two-tailed.

$*, * *$, and $* * *$ indicate significance at $\mathrm{p}<0.10, \mathrm{p}<0.05$, and $\mathrm{p}<0.01$, respectively. 
Table 4

Regressions of Total Contributions around GASB 67, Partitioned on the Expected Magnitude of Effect on Financial Statements

\begin{tabular}{|c|c|c|c|c|c|}
\hline & \multirow[t]{2}{*}{$\begin{array}{l}\text { Predicted } \\
\text { Sign } \\
\end{array}$} & \multicolumn{2}{|c|}{$\begin{array}{c}\text { Panel A: } \\
\text { High Funding Ratio }\end{array}$} & \multicolumn{2}{|c|}{$\begin{array}{c}\text { Panel B: } \\
\text { Low Funding Ratio }\end{array}$} \\
\hline & & Estimate & P-Value & Estimate & P-Value \\
\hline Intercept & & 0.526 & $<.0001 * * *$ & 0.720 & $<.0001 * * *$ \\
\hline POST-GASB 67 & + & 0.011 & 0.467 & 0.055 & $0.078 *$ \\
\hline Funding Ratio (Prior-Year) & $+/-$ & -0.354 & $0.001 * * *$ & -0.757 & $0.003 * * *$ \\
\hline \% Required Contributions Paid & + & 0.004 & 0.948 & 0.194 & $0.0004 * * *$ \\
\hline Plan Covers Teachers & + & -0.036 & $0.056 *$ & -0.002 & 0.909 \\
\hline Accrued Liability / Tax Revenue & $+/-$ & -0.005 & 0.279 & 0.066 & $0.090 *$ \\
\hline Unfunded Accrued Liability / Tax Revenue & $+/-$ & 0.007 & 0.873 & -0.229 & $0.041 * *$ \\
\hline Exp_Minus_Rev & - & -0.00006 & 0.353 & -0.00001 & 0.819 \\
\hline TTLBAL Ratio & $+/-$ & -0.033 & 0.751 & 0.020 & 0.373 \\
\hline Per Capita Short-Term Debt Issued & - & 0.000003 & 0.906 & -0.00003 & 0.923 \\
\hline Per Capita Growth in Gross State Product & + & 1.0741 & $0.043 * *$ & -0.0164 & 0.954 \\
\hline Balanced Budget & - & 0.002 & 0.613 & -0.013 & $0.005 * * *$ \\
\hline Union Membership & + & -0.108 & 0.583 & 0.178 & 0.406 \\
\hline Election & + & 0.010 & 0.127 & 0.005 & 0.605 \\
\hline Corruption & - & 0.005 & 0.741 & -0.008 & 0.610 \\
\hline Constitution & + & 0.002 & 0.935 & 0.045 & 0.185 \\
\hline Gratuity & - & -0.072 & $0.001 * * *$ & -0.063 & $0.073 *$ \\
\hline $\mathrm{N}$ & & 188 & & 212 & \\
\hline $\mathrm{R}^{2}$ & & $46.6 \%$ & & $62.6 \%$ & \\
\hline
\end{tabular}

Notes:

We partition our sample into two approximately equal-sized subsamples based on funding ratio measured in the year t-2.

Plans with funding ratios in year $\mathrm{t}-2$ below (above) the cutoff of 0.72 are assigned to the low (high) funding ratio subsample.

All variables are defined in Table 1.

Standard errors are clustered at the state level.

All model specifications include indicator variables for each quarter + year combination (e.g., Q1 2012, Q2 2012, Q3 2012, Q4 2012, Q1 2013, Q2 2013, etc.)

$*, * *$, and $* * *$ indicate significance at $\mathrm{p}<0.10, \mathrm{p}<0.05$, and $\mathrm{p}<0.01$, respectively. 
Table 5

Regressions of Total Contributions around GASB 67, Partitioned on Economic Consequences of GASB 67

\begin{tabular}{|c|c|c|c|c|c|}
\hline & \multirow[t]{2}{*}{$\begin{array}{c}\text { Predicted } \\
\text { Sign } \\
\end{array}$} & \multicolumn{2}{|c|}{$\begin{array}{c}\text { Panel A: } \\
\text { Low Short-Term Debt Issued }\end{array}$} & \multicolumn{2}{|c|}{$\begin{array}{c}\text { Panel B: } \\
\text { High Short-Term Debt Issued }\end{array}$} \\
\hline & & Estimate & P-Value & Estimate & P-Value \\
\hline Intercept & & 0.614 & $<.0001 * * *$ & 0.533 & $0.001 * * *$ \\
\hline POST-GASB 67 & + & 0.022 & 0.167 & 0.041 & $0.028 * *$ \\
\hline Funding Ratio (Prior-Year) & $+/-$ & -0.440 & $<.0001 * * *$ & -0.565 & $0.008 * * *$ \\
\hline$\%$ Required Contributions Paid & + & 0.060 & 0.473 & 0.155 & $0.001 * * *$ \\
\hline Plan Covers Teachers & + & -0.021 & 0.313 & -0.014 & 0.422 \\
\hline Accrued Liability / Tax Revenue & $+/-$ & -0.008 & $0.046 * *$ & 0.029 & 0.169 \\
\hline Unfunded Accrued Liability / Tax Revenue & $+/-$ & -0.037 & 0.109 & -0.127 & 0.115 \\
\hline Exp_Minus_Rev & - & 0.00007 & 0.172 & -0.00009 & 0.169 \\
\hline TTLBAL Ratio & $+/-$ & 0.076 & $<.0001 * * *$ & -0.054 & 0.184 \\
\hline Per Capita Short-Term Debt Issued & - & -0.0004 & $0.091 *$ & -0.00001 & 0.742 \\
\hline Per Capita Growth in Gross State Product & + & 0.310 & $0.486 * *$ & 0.7667 & 0.164 \\
\hline Balanced Budget & - & -0.007 & 0.195 & -0.003 & 0.439 \\
\hline Union Membership & + & -0.289 & 0.218 & 0.337 & $0.090 *$ \\
\hline Election & + & 0.019 & $0.059 *$ & 0.002 & 0.839 \\
\hline Corruption & - & -0.007 & 0.717 & -0.020 & 0.154 \\
\hline Constitution & + & 0.043 & 0.186 & 0.027 & 0.340 \\
\hline Gratuity & - & -0.088 & $0.0001 * * *$ & -0.039 & 0.108 \\
\hline $\mathrm{N}$ & & 188 & & 212 & \\
\hline $\mathrm{R}^{2}$ & & $69.2 \%$ & & $50.2 \%$ & \\
\hline
\end{tabular}

Notes:

We partition our sample into two approximately equal-sized subsamples based on values of the per capita short-term debt issued, measured in the year t-2.

Plans with per capita short-term debt issuances in year t-2 below (above) the cutoff of $\$ 0.03$ per capita are assigned to the low (high) short-term issuance subsample.

All variables are defined in Table 1.

Standard errors are clustered at the state level.

All model specifications include indicator variables for each quarter + year combination (e.g., Q1 2012, Q2 2012, Q3 2012, Q4 2012, Q1 2013, Q2 2013, etc.)

$*, * *$, and $* * *$ indicate significance at $\mathrm{p}<0.10, \mathrm{p}<0.05$, and $\mathrm{p}<0.01$, respectively. 
Table 6

Regressions of Total Contributions around GASB 67, Partitioned on Political Consequences of GASB 67

Intercept

\section{POST-GASB 67}

Funding Ratio (Prior-Year)

$\%$ Required Contributions Paid

Plan Covers Teachers

Accrued Liability / Tax Revenue

Unfunded Accrued Liability / Tax Revenue

\section{EXP_MINUS_REV}

TTLBAL Ratio

Per Capita Short-Term Debt Issued

Per Capita Growth in Gross State Product

Balanced Budget

Union Membership

Corruption

Constitution
Gratuity

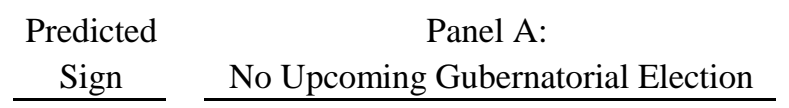

$\begin{array}{ll}\text { Sign } & \text { No Upcoming Gubernatorial Election } \\ \text { Estimate } \quad \text { P-Value }\end{array}$

$\begin{array}{clc} & 0.520 & <.0001 * * * \\ + & -0.016 & 0.643 \\ +/- & -0.440 & <.0001 * * * \\ + & 0.154 & 0.001 * * * \\ + & -0.020 & 0.080 * \\ +/- & 0.001 & 0.919 \\ +/- & -0.039 & 0.151 \\ - & 0.00001 & 0.856 \\ - & 0.036 & 0.128 \\ - & 0.00006 & 0.557 \\ + & 0.257 & 0.581 \\ - & -0.008 & 0.041 * * \\ + & 0.156 & 0.419 \\ - & -0.007 & 0.569 \\ + & 0.037 & 0.176 \\ - & -0.054 & 0.007 * * *\end{array}$

$\mathrm{N}$
$\mathrm{R}^{2}$
297

$57.4 \%$
Panel B:

Upcoming Gubernatorial Election

$\begin{array}{lc}\text { Estimate } & \text { P-Value } \\ 0.610 & <.0001 * * * \\ 0.116 & <.0001 * * * \\ -0.577 & 0.001 * * * \\ 0.114 & 0.068 * \\ -0.015 & 0.441 \\ 0.007 & 0.455 \\ -0.092 & 0.031 * * \\ -0.00007 & 0.410 \\ 0.061 & 0.082 * \\ -0.00009 & 0.481 \\ 1.230 & 0.093 * \\ -0.006 & 0.197 \\ 0.002 & 0.992 \\ -0.006 & 0.750 \\ 0.046 & 0.108 \\ -0.066 & 0.003 * * *\end{array}$

103

$57.8 \%$

Notes:

We partition our sample into two subsamples, based on whether there is a gubernatorial election in the next year.

All variables are defined in Table 1.

Standard errors are clustered at the state level.

All model specifications include indicator variables for each quarter + year combination (e.g., Q1 2012, Q2 2012, Q3 2012, Q4 2012, Q1 2013, Q2 2013, etc.)

$*, * *$, and $* * *$ indicate significance at $\mathrm{p}<0.10, \mathrm{p}<0.05$, and $\mathrm{p}<0.01$, respectively. 
Table 7

Determinants of Benefit Cuts around GASB 67

Intercept

Funding Ratio (Prior-Year)

$\%$ Required Contributions Paid

Plan Covers Teachers

Accrued Liability / Tax Revenue

Unfunded Accrued Liability / Tax Revenue

Exp_Minus Rev

TTLBAL Ratio

Per Capita Short-Term Debt Issued

Per Capita Growth in Gross State Product

Balanced Budget

Union Membership

Election

Corruption

Constitution

Gratuity

$\mathrm{N}$

$\mathrm{R}^{2}$

\begin{tabular}{ccc} 
Column 1 & & Column 2 \\
& & \\
Benefit & & Final \\
Multiplier & & Salary \\
Reduced & & Reduced \\
\cline { 1 - 1 } & & \\
\cline { 1 - 1 } Estimate & & Estimate \\
& & \\
$-7.450 * *$ & & -4.881 \\
4.983 & & 2.384 \\
0.701 & & -1.847 \\
-0.715 & & -0.629 \\
0.229 & & -0.056 \\
1.790 & & 1.637 \\
0.006 & & $0.007 * *$ \\
5.351 & & $8.074 * *$ \\
0.010 & & $0.018 * *$ \\
20.248 & & $-35.947 *$ \\
-0.078 & & 0.233 \\
8.052 & & 9.851 \\
$-16.700 * * * *$ & $-1.389 *$ \\
-0.143 & & -0.759 \\
$-1.793 *$ & -1.037 \\
$-15.496 * *$ & & -4.001
\end{tabular}

114

$37.3 \%$
Column 3

Retirement

Age

Increased

Estimate

$-5.845 *$

4.936

$-1.316$

0.035

$-0.419$

$2.618 *$

$0.005 * *$

$5.429 * *$

$0.016 * * * *$

$-19.573$

0.099

7.403

0.070

$-0.957$

0.125

$-2.929 * *$

114

$31.0 \%$

114
$28.6 \%$

Column 4

\begin{tabular}{c} 
COLA \\
Reduced \\
\hline
\end{tabular}

Estimate

$$
8.314 * *
$$

$-12.929 * * * *$

$-4.133 *$

$-2.237 * * *$

$1.551 * * *$

$-0.261$

$0.011 * * *$

$12.821 * * *$

$0.047 * * *$

$-76.690 * * * *$

0.198

$-8.639$

$-1.394$

$-2.374 * *$

$3.000 * *$

$-23.071 * * * *$

Column 5

Employee

Contributions

Increased

Estimate

$-3.256$

$4.888 *$

$-11.831$
114

$64.1 \%$
1.528

$-1.534$

0.134

$-0.433$

1.614

$0.004 *$

0.003

$0.267 * *$

$-1.276$

$-1.360 * *$

$-0.123$

$-1.261$

0.798
Column 6

Other

Benefit

Reductions

Estimate

\subsection{4}

$-3.504$

$-0.601$

$-0.880 *$

0.552

$-0.208$

$-0.002$

$-3.014$

0.011

$-8.909$

0.092

$-1.687$

1.002

$-0.198$

0.868

$-13.889 * * *$

114

$18.4 \%$
Column 7

Any

Benefit

Reductions

Estimate

$-1.911$

2.198

$-1.673$

$-0.030$

$-0.171$

1.373

0.003

2.759

$0.005 * *$

$-14.424$

0.160

0.234

$-0.005$

$-0.849$

0.897

$-0.276$

114

$24.2 \%$

Notes:

All explanatory variables are defined in Table 1.

All dependent variables, which are 0/1 indicators for each type of benefit cut, are defined in Appendix C.

Models are estimated using logistic regression, and are run at the plan-level, such that there is one observation per plan.

All independent variables are measured at year t-2 relative to GASB 67 adoption.

$*$, **, ***, and **** indicate significance at $\mathrm{p}<0.15, \mathrm{p}<0.10, \mathrm{p}<0.05$, and $\mathrm{p}<0.01$, respectively.

All p-values are two-tailed. We leave p-values untabulated for table readability. 
Table 8

Regressions of Total Contributions around GASB 67, Including Interactions for Benefit Cuts

\begin{tabular}{|c|c|c|c|c|c|}
\hline & $\begin{array}{c}\text { Predicted } \\
\text { Sign } \\
\end{array}$ & $\begin{array}{r}\text { Column } 1 \\
\text { Annual } \\
\text { Benefit } \\
\text { Capped } \\
\end{array}$ & $\begin{array}{c}\text { Column } 2 \\
\text { Benefit } \\
\text { Multiplier } \\
\text { Reduced } \\
\end{array}$ & $\begin{array}{c}\text { Column } 3 \\
\text { Final } \\
\text { Salary } \\
\text { Reduced } \\
\end{array}$ & $\begin{array}{c}\text { Column } 4 \\
\text { Retirement } \\
\text { Age } \\
\text { Increased } \\
\end{array}$ \\
\hline & & Estimate & Estimate & Estimate & Estimate \\
\hline Intercept & & $0.508 * * * *$ & $0.509 * * * *$ & $0.512 * * * *$ & $0.509 * * * *$ \\
\hline POST-GASB 67 & + & $0.032 * * * *$ & $0.030 * * * *$ & $0.031 * * * *$ & $0.030 * * * *$ \\
\hline Funding Ratio (Prior-Year) & $+/-$ & $-0.460 * * * *$ & $-0.458 * * * *$ & $-0.457 * * * *$ & $-0.457 * * * *$ \\
\hline$\%$ Required Contributions Paid & + & $0.137 * * * *$ & $0.136 * * * *$ & $0.133 * * * *$ & $0.135 * * * *$ \\
\hline Plan Covers Teachers & + & $-0.019 *$ & $-0.019 *$ & $-0.019 *$ & $-0.019 *$ \\
\hline Accrued Liability / Tax Revenue & $+/-$ & 0.002 & 0.002 & 0.002 & 0.002 \\
\hline Unfunded Accrued Liability / Tax Revenue & $+/-$ & $-0.049 * *$ & $-0.049 * *$ & $-0.048 * *$ & $-0.049 * *$ \\
\hline Exp_Minus_Rev & - & -0.00001 & -0.00001 & -0.00001 & -0.00001 \\
\hline TTLBAL Ratio & $+/-$ & $0.039 *$ & $0.039 *$ & $0.039 *$ & $0.039 *$ \\
\hline Per Capita Short-Term Debt Issued & - & -0.00005 & -0.00004 & -0.00004 & -0.00004 \\
\hline Per Capita Growth in Gross State Product & + & 0.464 & 0.492 & 0.483 & $0.496 *$ \\
\hline Balanced Budget & - & $-0.007 * *$ & $-0.006 * *$ & $-0.007 * *$ & $-0.007 * *$ \\
\hline Union Membership & + & 0.099 & 0.094 & 0.085 & 0.096 \\
\hline Election & + & 0.007 & 0.007 & 0.007 & 0.007 \\
\hline Corruption & - & -0.003 & -0.003 & -0.004 & -0.004 \\
\hline Constitution & + & $0.044 *$ & $0.046 *$ & $0.046 * *$ & $0.045 * *$ \\
\hline Gratuity & - & $-0.056 * * * *$ & $-0.055 * * * *$ & $-0.055 * * * *$ & $-0.055 * * * *$ \\
\hline Annual Benefit Capped & & $-0.072 * * * *$ & & & \\
\hline Annual Benefit Capped * POST-GASB 67 & & $0.096 * * *$ & & & \\
\hline Benefit Multiplier Reduced & & & -0.006 & & \\
\hline Benefit Multiplier Reduced * POST-GASB 67 & & & $0.051 *$ & & \\
\hline Final Salary Reduced & & & & -0.008 & \\
\hline Final Salary Reduced * POST-GASB 67 & & & & $0.054 * * *$ & \\
\hline Retirement Age Increased & & & & & -0.003 \\
\hline Retirement Age Increased * POST-GASB 67 & & & & & 0.027 \\
\hline $\mathrm{N}$ & & 400 & 400 & 400 & 400 \\
\hline $\mathrm{R}^{2}$ & & $55.6 \%$ & $55.6 \%$ & $55.6 \%$ & $55.5 \%$ \\
\hline
\end{tabular}

Notes:

All variables belonging to Equation (1) are defined in Table 1, and the 0/1 indicators for benefit cuts are defined in Appendix C.

In all columns, the dependent variable is total contributions scaled by prior-year covered payroll.

Standard errors are clustered at the state level.

All model specifications include indicator variables for each quarter + year combination (e.g., Q1 2012, Q2 2012, Q3 2012, etc.) $*, * *, * * *$, and $* * * *$ indicate significance at $\mathrm{p}<0.15, \mathrm{p}<0.10, \mathrm{p}<0.05$, and $\mathrm{p}<0.01$, respectively.

All p-values are two-tailed. We leave p-values untabulated for table readability. 
Table 8 (Continued)

Regressions of Total Contributions around GASB 67, Including Interactions for Benefit Cuts

\begin{tabular}{|c|c|c|c|c|c|}
\hline & $\begin{array}{c}\text { Predicted } \\
\text { Sign } \\
\end{array}$ & $\begin{array}{c}\text { Column } 5 \\
\text { COLA } \\
\text { Reduced } \\
\end{array}$ & $\begin{array}{c}\text { Column } 6 \\
\text { Employee } \\
\text { Contributions } \\
\text { Increased } \\
\end{array}$ & $\begin{array}{c}\text { Column } 7 \\
\text { Other } \\
\text { Benefit } \\
\text { Reductions } \\
\end{array}$ & $\begin{array}{l}\text { Column } 8 \\
\text { Any Benefit } \\
\text { Reductions } \\
\end{array}$ \\
\hline & & Estimate & Estimate & Estimate & Estimate \\
\hline Intercept & & $0.510 * * * *$ & $0.514 * * * *$ & $0.510 * * * *$ & $0.510 * * * *$ \\
\hline POST-GASB 67 & + & $0.031 * * * *$ & $0.032 * * * *$ & $0.030 * * * *$ & $0.032 * * * *$ \\
\hline Funding Ratio (Prior-Year) & $+/-$ & $-0.462 * * * *$ & $-0.458 * * * *$ & $-0.456 * * * *$ & $-0.456 * * * *$ \\
\hline$\%$ Required Contributions Paid & + & $0.134 * * * *$ & $0.131 * * * *$ & $0.135 * * * *$ & $0.133 * * * *$ \\
\hline Plan Covers Teachers & + & $-0.019 *$ & $-0.020 * *$ & $-0.019 *$ & $-0.019 *$ \\
\hline Accrued Liability / Tax Revenue & $+/-$ & 0.002 & 0.002 & 0.002 & 0.002 \\
\hline Unfunded Accrued Liability / Tax Revenue & $+/-$ & $-0.050 * *$ & $-0.047 * *$ & $-0.048 * *$ & $-0.048 * *$ \\
\hline Exp_Minus_Rev & - & -0.00001 & -0.00001 & -0.00001 & -0.00001 \\
\hline TTLBAL Ratio & $+/-$ & $0.039 *$ & $0.041 *$ & $0.040 *$ & $0.038 *$ \\
\hline Per Capita Short-Term Debt Issued & - & -0.00003 & -0.00005 & -0.00003 & -0.00005 \\
\hline Per Capita Growth in Gross State Product & + & 0.452 & 0.484 & 0.490 & 0.482 \\
\hline Balanced Budget & - & $-0.006 *$ & $-0.007 * *$ & $-0.007 * *$ & $-0.007 * *$ \\
\hline Union Membership & + & 0.102 & 0.078 & 0.089 & 0.093 \\
\hline Election & + & 0.008 & 0.007 & 0.007 & 0.006 \\
\hline Corruption & - & -0.003 & -0.004 & -0.003 & -0.004 \\
\hline Constitution & + & $0.044 * *$ & $0.043 *$ & $0.044 *$ & $0.046 *$ \\
\hline Gratuity & - & $-0.055 * * * *$ & $-0.053 * * * *$ & $-0.055 * * * *$ & $-0.055 * * * *$ \\
\hline COLA Reduced & & -0.018 & & & \\
\hline COLA Reduced * POST-GASB 67 & & $0.075 * * * *$ & & & \\
\hline Employee Contributions Increased & & & $-0.032 * *$ & & \\
\hline Employee Contributions Increased * POST- & SB 67 & & -0.003 & & \\
\hline Other Benefit Reductions & & & & 0.007 & \\
\hline Other Benefit Reductions * POST-GASB 67 & & & & -0.011 & \\
\hline Any Benefit Reductions & & & & & $-0.020 *$ \\
\hline Any Benefit Reductions * POST-GASB 67 & & & & & 0.010 \\
\hline $\mathrm{N}$ & & 400 & 400 & 400 & 400 \\
\hline $\mathrm{R}^{2}$ & & $55.8 \%$ & $55.9 \%$ & $55.4 \%$ & $55.7 \%$ \\
\hline
\end{tabular}

Notes:

All variables belonging to Equation (1) are defined in Table 1, and the 0/1 indicators for benefit cuts are defined in Appendix C. In all columns, the dependent variable is total contributions scaled by prior-year covered payroll. Standard errors are clustered at the state level.

All model specifications include indicator variables for each quarter + year combination (e.g., Q1 2012, Q2 2012, Q3 2012, etc.) $*, * *, * * *$, and $* * * *$ indicate significance at $\mathrm{p}<0.15, \mathrm{p}<0.10, \mathrm{p}<0.05$, and $\mathrm{p}<0.01$, respectively.

All p-values are two-tailed. We leave $\mathrm{p}$-values untabulated for table readability. 